\title{
Article \\ Natural vs. Synthetic Phosphate as Efficient Heterogeneous Compounds for Synthesis of Quinoxalines
}

\author{
Abbas Amini ${ }^{1,2, *(\mathbb{D})}$, Azadeh Fallah ${ }^{3}$, Ahmad Sedaghat ${ }^{2} \mathbb{D}$, Ahmad Gholami ${ }^{4,5} \mathbb{D}$, Chun Cheng $^{6}$ \\ and Anju R. Gupta ${ }^{7}$
}

1 Centre for Infrastructure of Engineering, Bld Z, Locked Bag 1797, Kingswood Campus, Western Sydney University, Penrith, NSW 2751, Australia

2 Department of Mechanical Engineering, Australian College of Kuwait, Mishref, Safat 13015, Kuwait; a.sedaghat@ack.edu.kw

3 Department of Chemistry, Payame Noor University, Tehran 19395-4697, Iran; azadehfallah84@gmail.com

4 Pharmaceutical Sciences Research Center, Shiraz University of Medical Sciences, Shiraz 71348-14336, Iran; Gholami@sums.ac.ir

5 Department of Pharmaceutical Biotechnology, School of Pharmacy, Shiraz University of Medical Sciences, Shiraz 71348-14336, Iran

6 Department of Materials Science and Engineering, Southern University of Science and Technology (SUSTech), Shenzhen 518055, China; chengc@sustech.edu.cn

7 Department of Mechanical Engineering, Industrial and Manufacturing Engineering, The University of Toledo, Toledo, OH 43606, USA; anju.gupta@utoledo.edu

* Correspondence: a.amini@ack.edu.kw; Tel.: +61-2-404060787; Fax: +61-2-9685-9298

check for

updates

Citation: Amini, A.; Fallah, A.; Sedaghat, A.; Gholami, A.; Cheng, C.; Gupta, A.R. Natural vs. Synthetic Phosphate as Efficient Heterogeneous Compounds for Synthesis of Quinoxalines. Int. J. Mol. Sci. 2021, 22, 13665. https://doi.org/10.3390/ ijms222413665

Academic Editor:

Salah-Eddine Stiriba

Received: 21 October 2021

Accepted: 17 December 2021

Published: 20 December 2021

Publisher's Note: MDPI stays neutral with regard to jurisdictional claims in published maps and institutional affiliations.

Copyright: (c) 2021 by the authors. Licensee MDPI, Basel, Switzerland. This article is an open access article distributed under the terms and conditions of the Creative Commons Attribution (CC BY) license (https:/ / creativecommons.org/licenses/by/ $4.0 /)$.

\begin{abstract}
Natural phosphate (NP) and synthetic fluorapatite phosphate (SFAP) were proposed as stable, inexpensive, readily available and recyclable catalysts for the condensation of 1,2-diamines with 1,2-dicarbonyls in methanol to afford quinoxaline at room temperature. NP provided as high as 92-99\% yield for quinoxalines in short reaction times (i.e., 1-45 $\mathrm{min}$ ), while SFAP created quinoxalines with $87-97 \%$ yield in 60-120 min. From the chemical analyses, X-ray fluoresecency, X-ray diffraction, energy dispersive $\mathrm{X}$-ray and Fourier-transform infrared spectroscopy methods, two main phases $\left(\mathrm{CaO}, \mathrm{P}_{2} \mathrm{O}_{5}\right)$ appeared in NP together with other low content phases $\left(\mathrm{SiO}_{2}, \mathrm{Fe}_{2} \mathrm{O}_{3}\right)$. Compared to other phases, apatite $\left(\mathrm{CaO}\right.$ and $\mathrm{P}_{2} \mathrm{O}_{5}$ as $\left.\mathrm{Ca} 10\left(\mathrm{PO}_{4}\right)_{6}\right)$ played a major role in the catalytic activity of $\mathrm{NP}$. SFAP with similar $\mathrm{Ca} / \mathrm{P}$ atomic ratio showed a relatively lower catalytic activity than NP for the condensation of 1,2-diamine with 1,2-dicarbonyl in methanol at ambient temperature. To investigate the recyclability of catalysts, the surface properties of NP and 6-recycled NP were investigated using scanning electron microscopy, energy dispersive X-ray and Brunauer-Emmett-Teller and BarrettJoyner-Halenda methods. Some differences were observed in NP and 6-recycled NP's particle size, surface area, the volume and size of pores, and the content of elements; nevertheless, the use-reuse process did not noticeably change the catalytic property of NP.
\end{abstract}

Keywords: heterogeneous catalyst; natural phosphate; fluorapatite; quinoxalines; apatite; nano-biochemistry

\section{Introduction}

Nature-based benign procedures require mild reaction conditions, easy purification, waste management and kinetic enhancement [1]. It becomes clear that the association of heterogeneous catalysis presents an open window of opportunities to advance chemical reactions because of the potential for enhancing the efficiency, selectivity and reusability of catalysts. Natural agents and biodegradable heterogeneous catalysts, i.e., inorganic solids (zeolite [2], silica [3], alumina [4], clay [5], etc.), can play a key role in the field of sustainable chemistry by reducing cost and waste disposal through mild catalytic processes [6]. In parallel, mineralogical classes of natural phosphate (NP), which generally belong to the family of phosphocalcic apatites $\left(\mathrm{Ca}_{10}\left(\mathrm{PO}_{4}\right)_{6} \mathrm{X}_{2}, \mathrm{X}=\mathrm{OH}\right.$ and $\left.\mathrm{F}\right)$, can be exploited to acquire 
hydroxyl and fluorapatite in their pure state [7-9]. Natural phosphate (apatite) and synthetic fluorapatite phosphate have been used $[8,10]$ as the catalysts for Claisen-Schmidt condensation [11], the hydration of nitriles [12] and the oxidation of cyclic ketones to keto acids [13], tetraketones [14], xanthenes [14,15] and 1,4-disubstituted-1,2,3-triazoles [15]. In the present study, the main components of the newly used NP are investigated and its catalytic effects for the synthesis of quinoxaline are assayed.

Quinoxalines have attracted significant attention due to their various applications as base materials for dyes [16], optoelectronic and luminescent materials [17], semiconductors [18] and inhibitors [19]. Quinoxaline moiety has been used for the synthesis of biologically active compounds with antitumor [20,21], antiviral [22], anti-inflammatory [23], anti-HIV [24] and anticancer [25] properties. Various strategies for the synthesis of quinoxalines have been proposed by using different catalysts, such as aqueous hydrofluoric acid and gadolinium chloride [26], magnetic clayzic [27], alkyl sulfonate functionalized metal organic framework (MOF), MIL-101-Cr-NH-RSO ${ }_{3} \mathrm{H}$ [28], thiamine hydrochloride ( $\mathrm{VB}_{1}$ ) [29], Zr-CAP-SG [30], Cu (BDC) [31], sulfonated nanoclay [32], arabic gum [1], sulphated polyborate [33], nano-particles $\mathrm{ZrO}_{2}$ [34], nanostructured pyrophosphate [21] and magnetic material separated from coal fly ash [35] through the condensation of 1,2-diketones with 1,2-diamines. These methods need a higher quantity of catalyst and suffer from a long reaction time, harsh conditions, multi-step processes for the preparation of the catalyst and high costs.

Here, NP and SFAP were used as the catalysts (see Scheme 1) for the synthesis of quinoxaline with excellent yield under mild conditions. As the structure of NP was similar to that of fluorapatite $\left(\mathrm{Ca}_{10}\left(\mathrm{PO}_{4}\right)_{6} \mathrm{~F}_{2}\right)$, we prepared SFAP through the co-precipitation method [36] and compared its structure and catalytic activity with NP. In short, NP was found as a perfect natural catalyst and performed better than SFAP in the condensation reaction of a series of 1,2-diketones with 1,2-diamines in methanol to successfully afford quinoxalines with excellent yields at room temperature (rt).

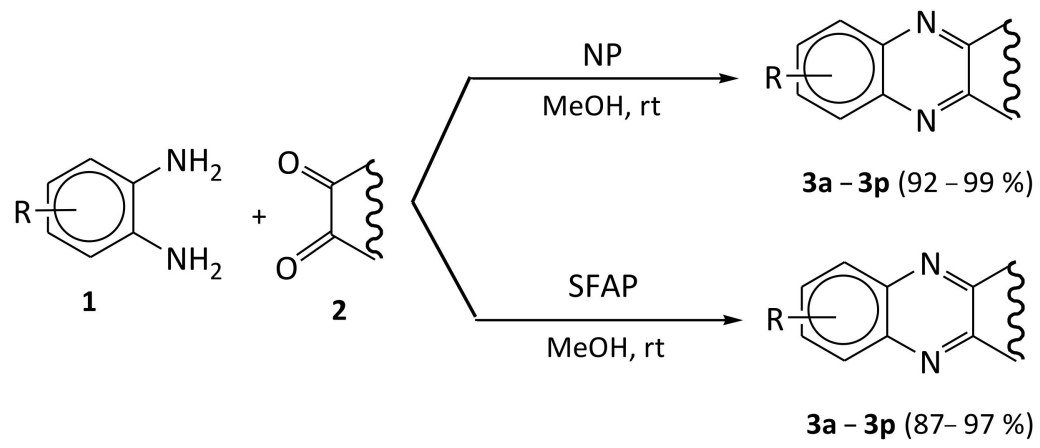

Scheme 1. NP and SFAP as heterogeneous catalysts for the synthesis of quinoxalines.

\section{Results and Discussion}

\subsection{Characterization of NP and SFAP}

The structures of NP and SFAP were characterized using Fourier-transform infrared spectroscopy (FT-IR), scanning electron microscopy (SEM), energy dispersive $X$-ray analysis (EDX), Brunauer-Emmett-Teller and Barrett-Joyner-Halenda (BET and BJH) methods, $\mathrm{X}$-ray fluorescence $(\mathrm{XRF})$ and $\mathrm{X}$-ray diffraction $(\mathrm{XRD})$. The NP structure was similar to the reported synthetic fluorapatite in the literature [36] and Morocco's natural phosphate [37,38]. The structure of SFAP was found to be similar to the reported synthetic fluorapatite in the literature [36]. These analyses could help us to assess the properties of these inorganic compounds and determine the rationale for their catalytic activities and their differences.

\subsubsection{FT-IR Spectroscopy}

The FT-IR spectra of NP and SFAP are presented in Figure 1. A number of bands in the spectra were located between $1000-1100 \mathrm{~cm}^{-1}$, including those at $1092-5$ and $1044-9 \mathrm{~cm}^{-1}$. 
These bands were assigned to triply degenerate asymmetric stretching modes of $\mathrm{P}-\mathrm{O}$ $\left(v_{3}\right)$ vibrations of the phosphate group. The peak at $962 \mathrm{~cm}^{-1}$ was assigned to a nondegenerated symmetric stretching mode $\left(v_{1}\right)$ of $\mathrm{P}-\mathrm{O}$ bond of the phosphate group. The bands at 600 and $576 \mathrm{~cm}^{-1}$ were from triply degenerate asymmetric bending modes $\left(v_{4}\right)$ of phosphate $\mathrm{O}-\mathrm{P}-\mathrm{O}$ bonds, while the weak peaks at $473 \mathrm{~cm}^{-1}$ were ascribed to doubly degenerate bending mode $\left(v_{2}\right)$ of the phosphate group $(\mathrm{O}-\mathrm{P}-\mathrm{O}$ bond) [39-42].

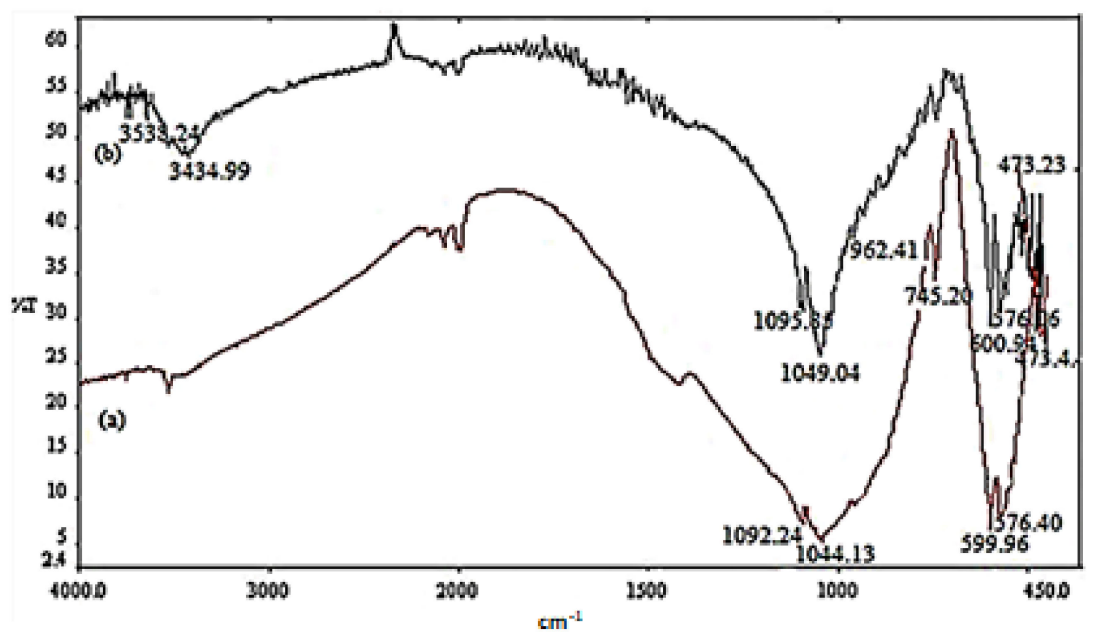

Figure 1. FT-IR spectra of: (a) NP, and (b) SFAP.

\subsubsection{XRF Analysis}

The chemical compositions of NP were determined as $\mathrm{P}_{2} \mathrm{O}_{5}(37.61 \%), \mathrm{CaO}(48.53 \%)$, $\mathrm{MgO}(1.16 \%), \mathrm{SiO}_{2}(4.26 \%), \mathrm{Fe}_{2} \mathrm{O}_{3}(5.26 \%), \mathrm{F}(2.86 \%), \mathrm{Cl}(0.13 \%), \mathrm{TiO}_{2}(0.25 \%), \mathrm{Ce}_{2} \mathrm{O}_{3}$ $(0.86 \%), \mathrm{La}_{2} \mathrm{O}_{3}(0.4 \%) \mathrm{Nd}_{2} \mathrm{O}_{3}(0.42 \%), \mathrm{Y}_{2} \mathrm{O}_{3}(0.26 \%), \mathrm{Al}_{2} \mathrm{O}_{3}(0.19 \%), \mathrm{MnO}(0.08 \%), \mathrm{Na}_{2} \mathrm{O}$ $(0.28 \%), \mathrm{K}_{2} \mathrm{O}(0.06 \%) \mathrm{SO}_{3}(0.32 \%)$ [14], and for SFAP, they were: $\mathrm{P}_{2} \mathrm{O}_{5}(40.71 \%)$ and $\mathrm{CaO}$ $(57.69 \%)$ and $\mathrm{F}(2.16 \%)$. The chemical components of NP were similar to SFAP; this is also supported by the data found in the literature on fluorapatite $\left(\mathrm{Ca}_{10}\left(\mathrm{PO}_{4}\right)_{6} \mathrm{~F}_{2}\right)$ in Morocco natural phosphate [43]. According to previous reports, the $\mathrm{Ca} / \mathrm{P}$ atomic ratio of apatites is approximately 1.67 , based on their chemical formula for standard apatite; the calcium deficiency can lower the $\mathrm{Ca} / \mathrm{P}$ atomic ratio to $1.5[42,44,45]$. The $\mathrm{Ca} / \mathrm{P}$ atomic ratios of NP (48.5/37.6) and SFAP (57.69/40.71) were reported with the values of 1.61 and 1.58, respectively, which are within the acceptable range for apatite (1.5-1.67).

\subsubsection{XRD Analysis}

XRD patterns of NP [14] and SFAP (Figure 2) show that they are well-crystalline with fluorapatite-type structures and the peaks fitted with PDF\#01-015-876 [46] (Figure 1b, Supplementary Information, SI); the sharp and distinct peaks demonstrate a high degree of crystallinity. Based on the available crystallographic data for NP and SFAP, NP belongs to the same space group as SFAP; the hexagonal system of crystallite with the space group of $\mathrm{P}_{3} / \mathrm{m}$. The lattice parameters of NP and SFAP are in excellent agreement with the standard data [36]; for NP, $\mathrm{a}=9.381 \AA$ and $\mathrm{c}=6.900 \AA$ and $\mathrm{V}=526.86 \AA^{3}$, and for SFAP, $\mathrm{a}=9.3684 \AA$ and $\mathrm{c}=6.8841 \AA$ and $\mathrm{V}=523.25 \AA^{3}$. The crystallite sizes of NP and SFAP were calculated through the Debye-Scherrer equation (Equation (1)) using XRD data of NP and SFAP and X'Pert High Score Plus program:

$$
D=0.9 \lambda\left(\beta_{0.5}\right)^{-1}(\cos \theta)^{-1}
$$

where $D$ is the average crystallite size ( $156 \mathrm{~nm}$ for NP and $76 \mathrm{~nm}$ for SFAP); $\lambda$, the wavelength of X-ray used $(0.154 \mathrm{~nm}$ for $\mathrm{Cu}) ; \beta_{0.5}$, the line broadening at the half maximum intensity after subtracting the instrumental line broadening in radians; and $\theta$, Bragg angle in degree [47]. The average values of crystallite size determined for both NP and SFAP 
particles show that, for (0 0 2), (2 1 1), (3 0 0), (3 1 0) Miller's planes (except (2 2 2)), they have higher intensity than others (see Figure 2). Despite the larger average crystallite size of NP than SFAP (Table 1), NP possesses higher catalytic activity in the synthesis of quinoxaline.

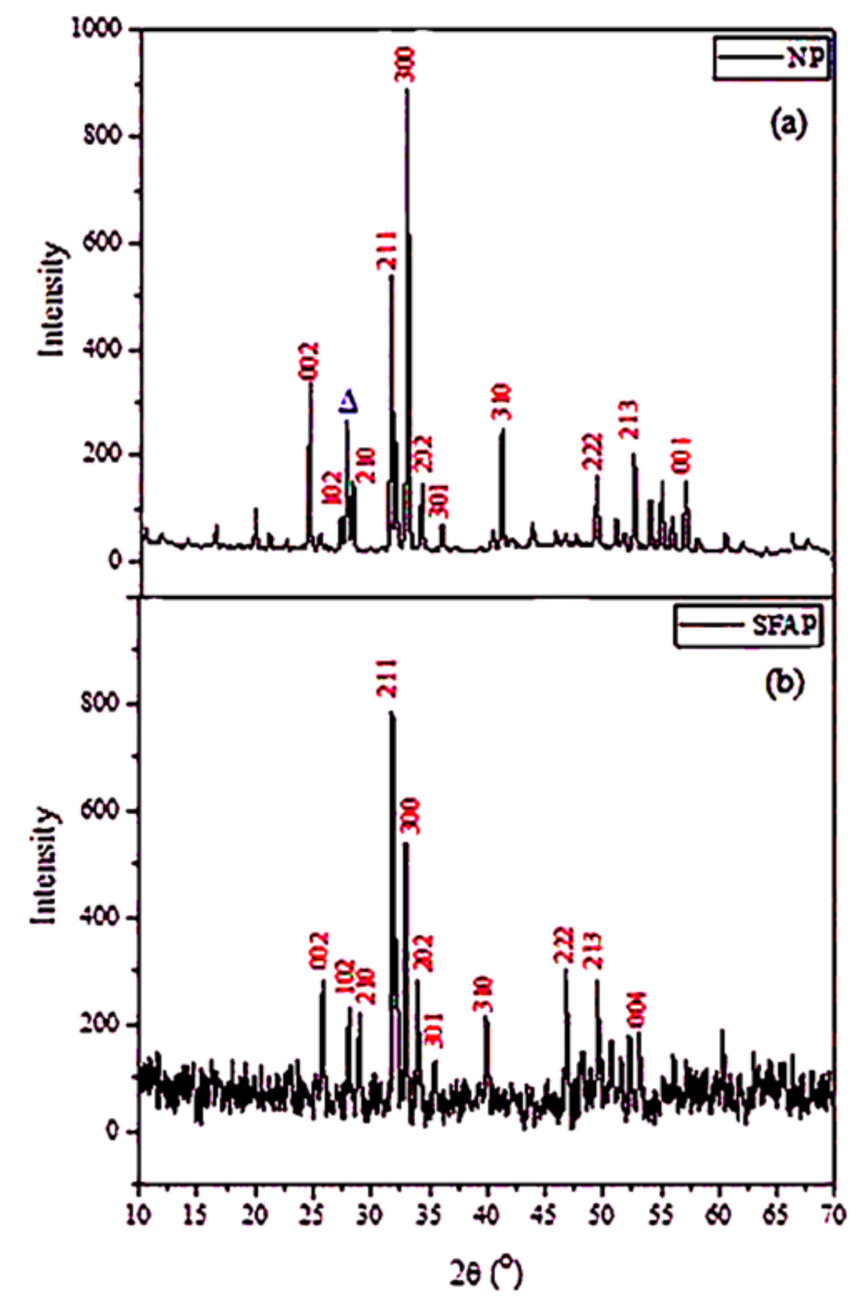

Figure 2. XRD patterns of: (a) NP; the blue triangle is showing the diffraction peak of coesite, $\mathrm{SiO}_{2}$ (JCPDS 72-1601) [48], and (b) SFAP. (Red numbers represent the crystalline planes).

Table 1. Average crystallite size of the samples.

\begin{tabular}{ccc}
\hline Entry & Sample & $\begin{array}{c}\text { Average Crystallite Size } \\
\text { D (nm) }\end{array}$ \\
\hline 1 & NP & 155.76 \\
2 & SFAP & 75.98 \\
\hline
\end{tabular}

\subsection{4. $\mathrm{pH}$ Value of Surface}

To obtain the basicity of the surface of NP, the $\mathrm{pH}$ of the surface was determined as 10.34 at the point of zero charge $\left(\mathrm{pH}_{\mathrm{pzc}}\right)$ (Figure 3) [49]. Thus, the presence of basic sites on the surface of NP induced the co-adsorption of substrate molecules. This alteration plays a key role in devising a more effective approach on the collision of the catalyst with the organic substrate. The $\mathrm{pH}_{\mathrm{pzc}}$ for a mineral is the value at which the surface has a negative charge, so, when $\mathrm{pH}<\mathrm{pH}_{\mathrm{pzc}}$, the surface possesses positive charge in a solution, whereas the negative charge occurs when $\mathrm{pH}>\mathrm{pH}_{\mathrm{pzc}}$. These effects can be explained by the deprotonation or protonation of phosphate $\mathrm{P}-\mathrm{O}(\mathrm{H})$ [50] and calcium oxide $\mathrm{Ca}-\mathrm{O}(\mathrm{H})$ [51] groups in the framework of NP. So, it is reasonable to choose the external surface of NP as the basic surface. 


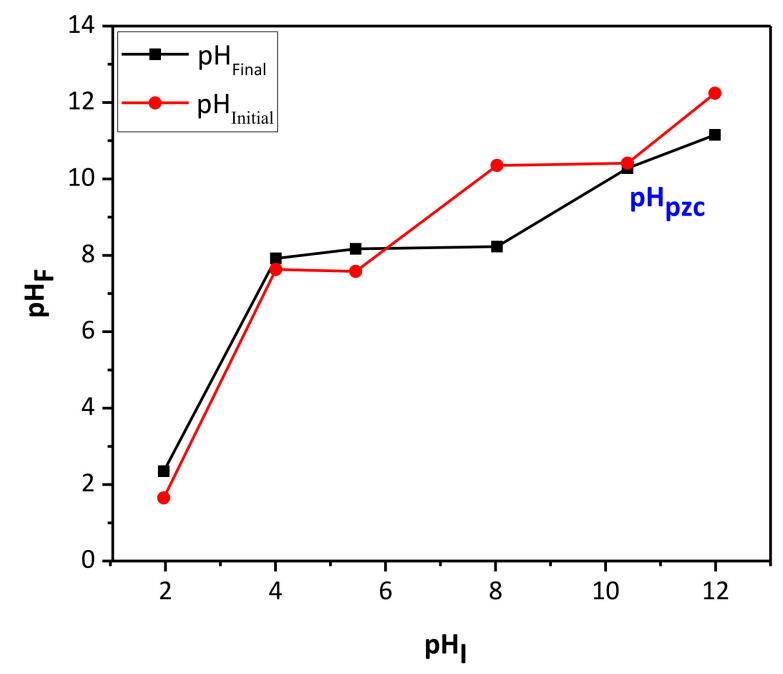

Figure 3. Determining $\mathrm{pH}_{\mathrm{pzc}}$ of NP.

\subsection{Reusability of Catalyst}

\subsubsection{BET and BJH Methods}

Recent studies suggest that finding the specific surface area is often a prerequisite for quantizing and interpreting adsorption properties [15]. To determine the role of NP catalytic activity in the model reaction, we characterized the specific surface areas of NP after six recycling runs (6-recycled NP) for the model reaction. The specific surface areas and pore size distributions of NP and 6-recycled NP were measured through the nitrogen adsorption-desorption isotherms using BET and BJH methods. According to BET results, the adsorption isotherms of NP and 6-recycled NP were classified as type IV with a $\mathrm{H}_{3}$ hysteresis loop at $\mathrm{P} / \mathrm{P}_{0} \sim 0.98$; then, according to Brunauer-Deming-Deming-Teller (BDDT) classification [52], they were categorized as mesoporous solids [53] (Figure 4).
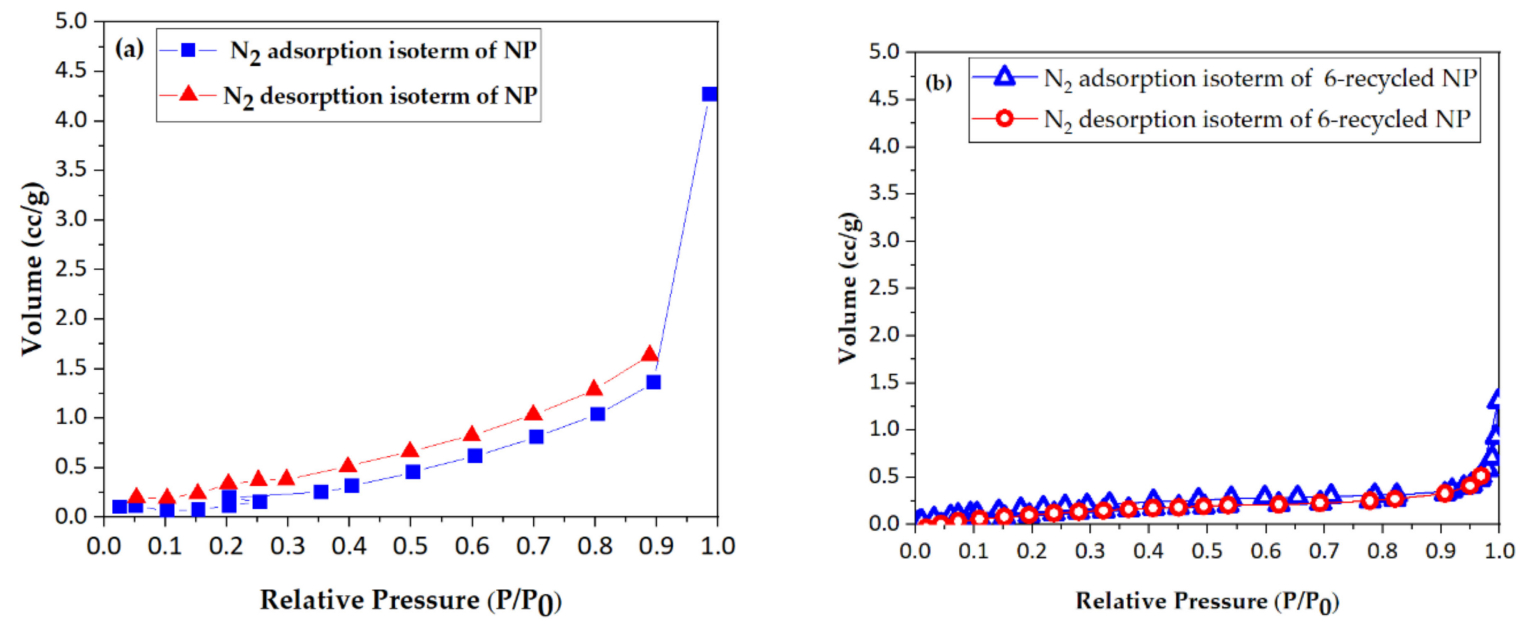

Figure 4. $\mathrm{N}_{2}$ adsorption-desorption isotherm (BET) of: (a) NP, and (b) 6-recycled NP.

Pore volume and size distributions of NP and 6-recycled NP were analyzed by using the BJH method for the $\mathrm{N}_{2}$ adsorption branch isotherms (Figure 5, Table 2). The surface areas of these particles are considered low [54] as per $\mathrm{S}_{\mathrm{BET}}=2.081$ and $\mathrm{S}_{\mathrm{BJH}}=1.948 \mathrm{~m}^{2} \mathrm{~g}^{-1}$ for NP, and $S_{B J H}=0.761$ and $S_{B J H}=0.426 \mathrm{~m}^{2} \mathrm{~g}^{-1}$ for recycled NP. There is no noticeable porosity as per the pore volume of $0.007 \mathrm{~cm}^{3} \mathrm{~g}^{-1}$ for NP with the average size of $3.675 \mathrm{~nm}$, and $0.001 \mathrm{~cm}^{3} \mathrm{~g}^{-1}$ for 6-recycled NP with the average pore size of $5.784 \mathrm{~nm}$. These results are in good agreement with the reported data for Morocco natural phosphate [12,55]. By comparing the specific surface area and average pore volume of NP and 6-recycled NP, it is 
concluded that the recycled NP has lower porosity and specific surface area, which can be responsible for its lower catalytic activity [56]. The very low surface area of 6-recycled NP may facilitate the strong adsorption of a small amount of either quinoxaline or other unknown by-products [54]. The reduction in surface area in recycled NP may also occur during the calcination, attributing to the coalescence of NP particles [57].
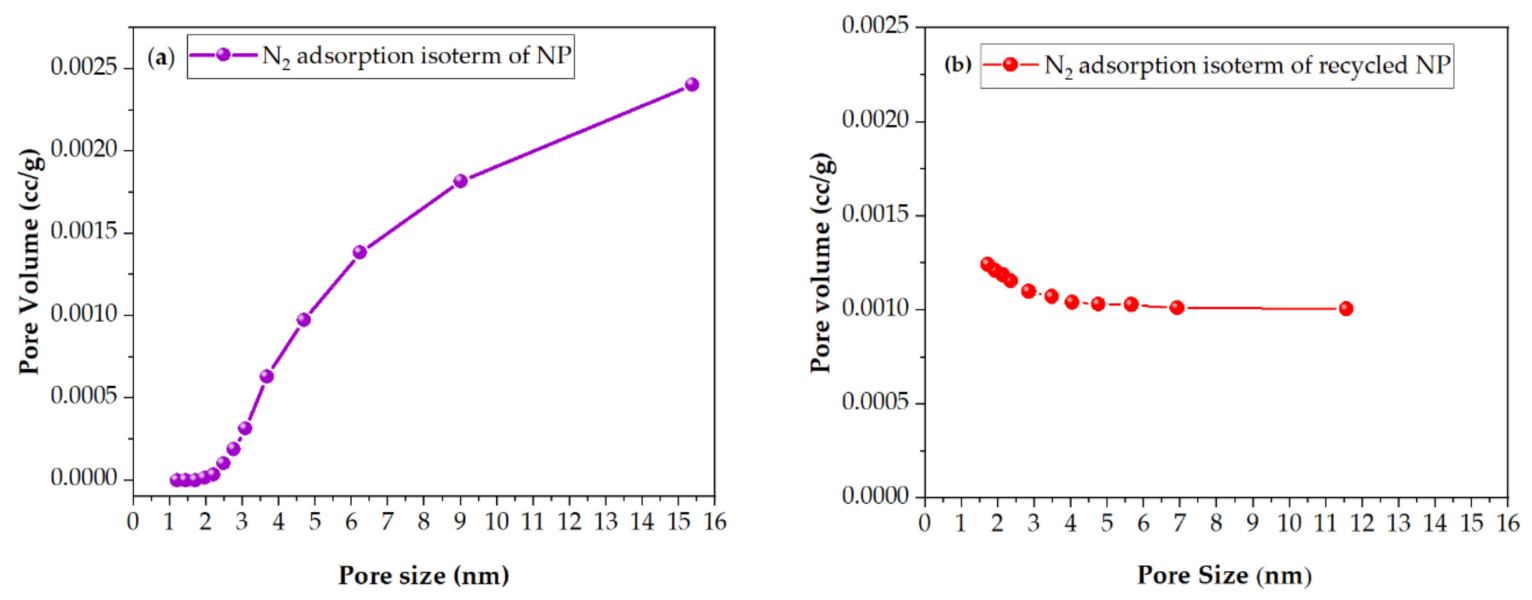

Figure 5. Pore size distributions curve (BJH) of: (a) NP, and (b) 6-recycled NP.

Table 2. Surface area, pore volume and average pore size of NP and 6-recycled NP.

\begin{tabular}{cccc}
\hline Catalyst & Surface Area $\left(\mathbf{m}^{2} / \mathbf{g}\right)$ & Pore Volume $\left(\mathbf{c m}^{3} / \mathbf{g}\right)$ & Average Pore Size $(\mathbf{n m})$ \\
\hline NP & $2.081(\mathrm{BET}) 1.948(\mathrm{BJH})$ & 0.007 & 3.675 \\
6-recycled NP & $0.761(\mathrm{BET}) 0.426(\mathrm{BJH})$ & 0.001 & 5.784 \\
\hline
\end{tabular}

\subsubsection{SEM Analysis}

The surface morphology of NP and 6-recycled NP was investigated using the SEM method (Figure 6). As depicted in Figure 6b, the 6-recycled NP is shown at different magnifications to visualize the detailed surface change which indicates insignificant differences. It contains particles with an average diameter of $282-591.8 \mathrm{~nm}$ and a uniform distribution without significant aggregation [53]. The small particles in Figure $6 \mathrm{~b}$ may be hematite $\left(\mathrm{Fe}_{2} \mathrm{O}_{3}\right)$ which are replaced with hydroxyl ions from phosphate and have catalytic activity [58].

\subsubsection{EDX Analysis}

EDX spectra in Figure 7 show that both NP and 6-recycled NP consist of constituent elements of $\mathrm{Ca}, \mathrm{P}, \mathrm{Si}, \mathrm{Fe}$ and $\mathrm{O}[47,59]$. As seen in Figure 7b, there is a marginal loss for $\mathrm{Fe}$ atoms during the reaction and recycling process. Two oxygen atoms in phosphate ion $\left(\mathrm{PO}_{4}{ }^{3-}, \mathrm{P}_{2} \mathrm{O}_{5}\right)$ are coordinated, each one to a $\mathrm{Fe}^{3+}$ ion, creating a binuclear surface complex of Fe-O-P $\left(\mathrm{O}_{2}\right)-\mathrm{O}-\mathrm{Fe}$. The phenomenon of phosphate adsorption in Scheme 2 presents the creation route of this coordination structure on the surface of NP. Two surface oxygen groups of NP exist in intermediate I and II (shown in Scheme 3), by which the aminic hydrogen (NH) of diamine can form a doubly H-bonded composition to give hydroxyl (see structures 1 and 2, Schemes 2 and 3); subsequently, they are replaced with one oxygen of phosphate group $\left(\mathrm{P}_{2} \mathrm{O}_{5}\right)$ of NP [60-62]. It is confirmed that gray-to-black-colored particles that appeared on the recycled NP is hematite $\left(\mathrm{Fe}_{2} \mathrm{O}_{3}\right)$, which is released from NP during the reaction $[63,64]$. This can be the cause of the decreasing catalytic activity of recycled NP in the model reaction [65]. 


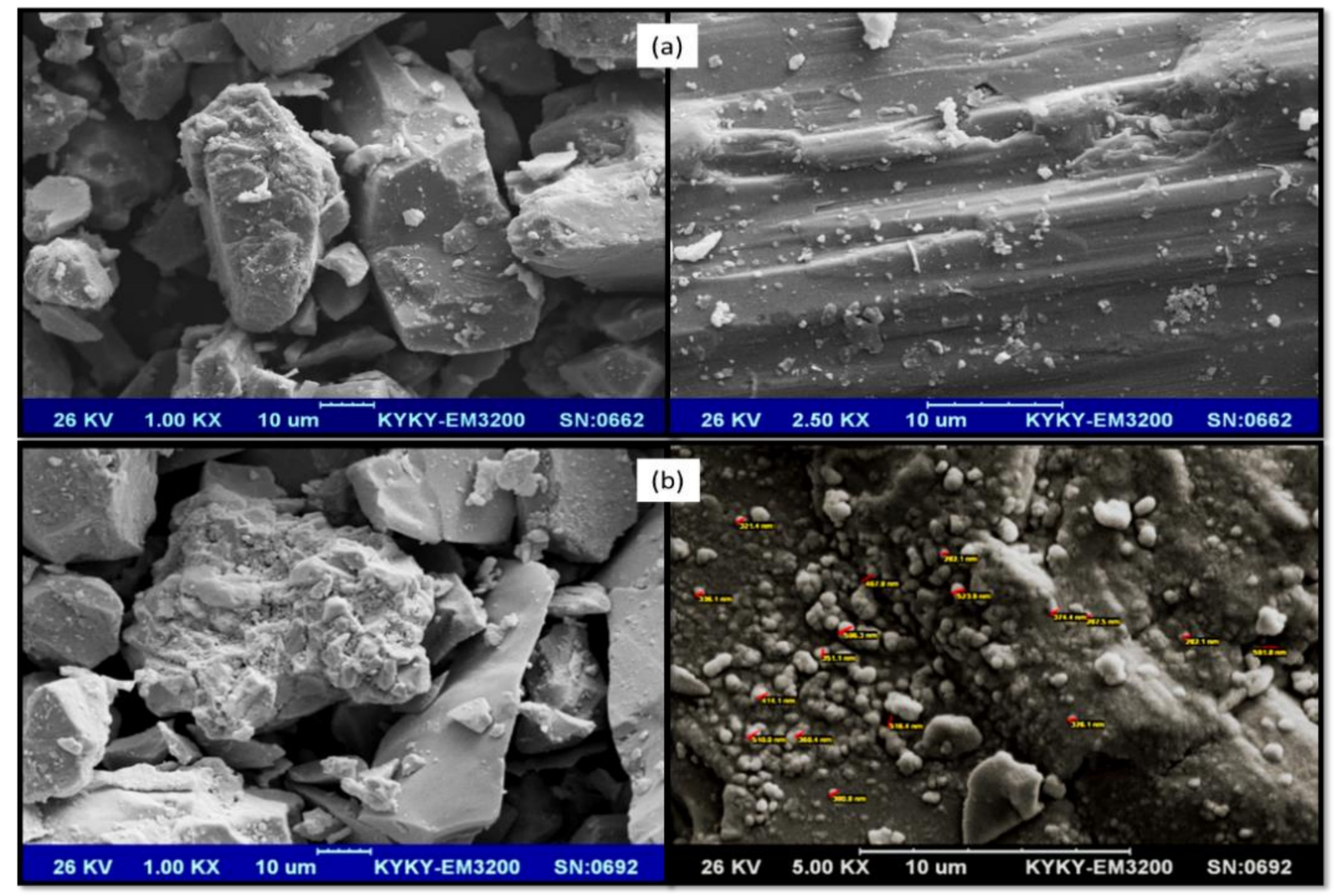

Figure 6. SEM images of: (a) NP, and (b) 6-recycled NP.
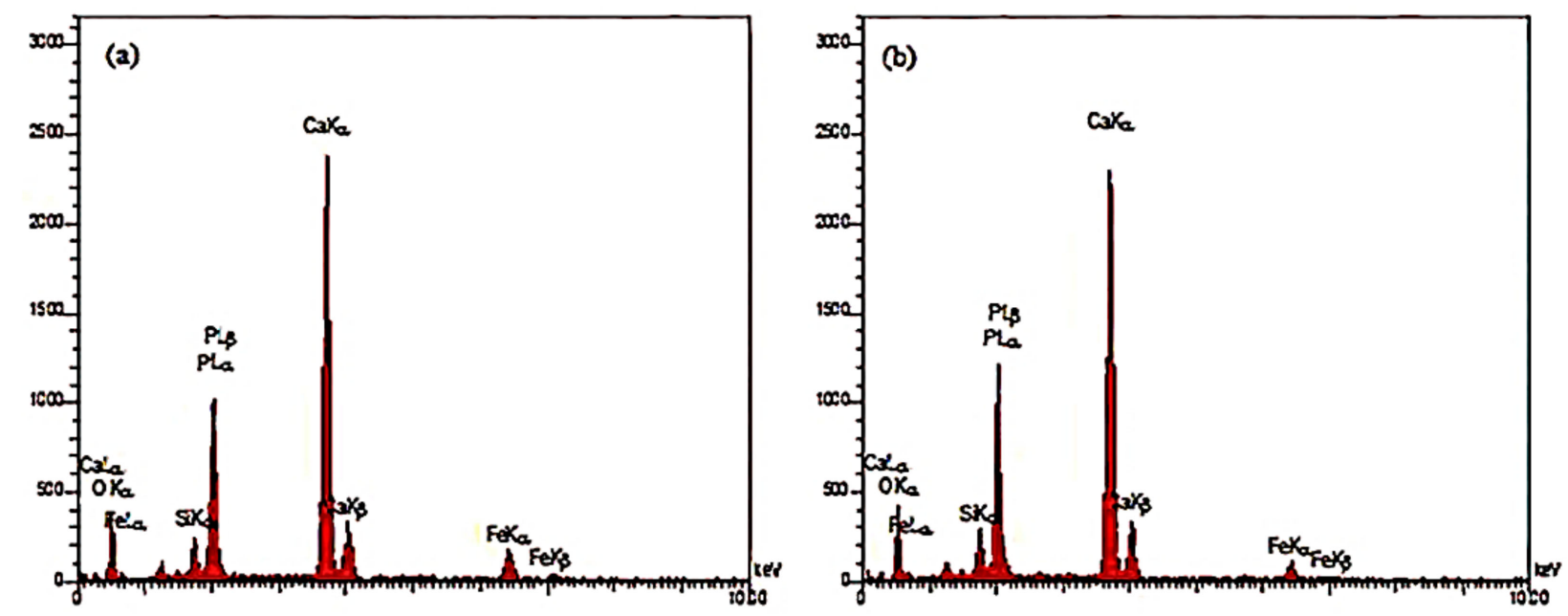

Figure 7. EDX spectra of: (a) NP and (b) 6-recycled NP. 
<smiles>[O][PH]([O])(O[Po]O)O[Po]O</smiles>

(1)<smiles>[O-][PH](O[Po])(O[Po])OPO</smiles>

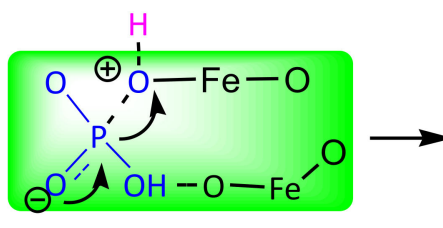

NP

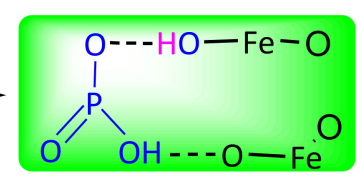

NP

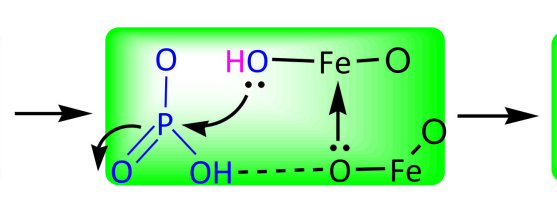

NP<smiles>[O-][P+3]O</smiles>

Recycled NP

Scheme 2. NP is composed of different oxides $\left(\mathrm{P}_{2} \mathrm{O}_{5}, \mathrm{CaO}, \mathrm{Fe}_{2} \mathrm{O}_{3}\right.$ and $\left.\mathrm{SiO}_{2}\right)$ that are placed together in its crystalline structure. In the proposed mechanism for the reaction by NP as the catalyst (Scheme 3), surface oxygens of NP adsorbed hydrogens of amino group $(\mathrm{N}-\mathrm{H})$ through hydrogen bonding to form hydroxyl group on these oxides like hematite $\left(\mathrm{Fe}_{2} \mathrm{O}_{3}\right)$. Through hydrogen bonding, this protonated hematite is adsorbed on phosphate to form binuclear complex of hematite $\left(\mathrm{Fe}_{2} \mathrm{O}_{3}\right)$ and phosphate $\left(\mathrm{P}_{2} \mathrm{O}_{5}, \mathrm{PO}_{4}{ }^{3-}\right)$, or $\mathrm{HFe}_{3} \mathrm{PO}_{7}(\mathbf{1}$ and 2$)$. Hydrogen atom in hydrogen bonding could be closer either to oxygen atoms of (1) hematite or (2) phosphate. (3) Proposed mechanism for the $\mathrm{Fe}_{2} \mathrm{O}_{3}$ losses from NP during the reactions [63].

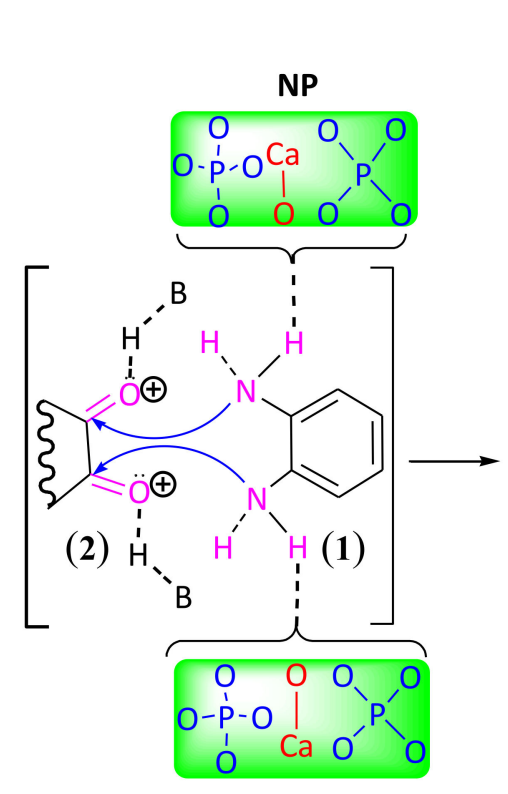

Intermediate I

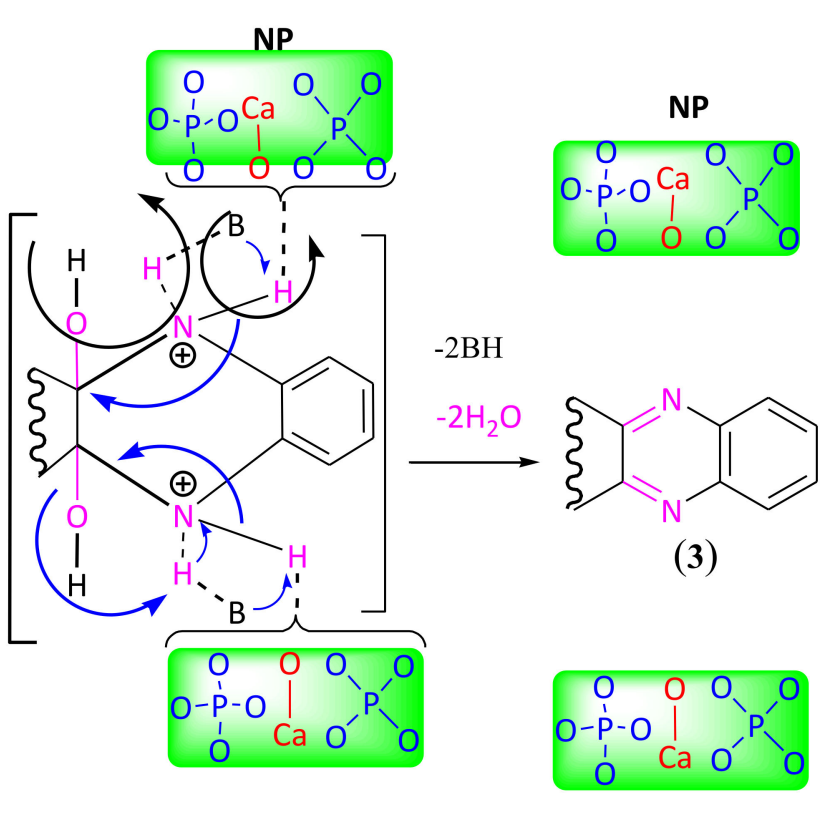

Intermediate II

Scheme 3. Proposed mechanism for the synthesis of quinoxaline using NP as the catalyst.

\subsection{Synthesis of Quinoxaline}

The reaction conditions were optimized for the condensation of 1,2-phenylenediamine $\mathbf{1 a}(1 \mathrm{mmol})$ and benzil $\mathbf{2 a}(1 \mathrm{mmol})$ in the model reaction. First, the reaction was carried out by using different protic and aprotic solvents (Table 3). The protic solvents showed better results than aprotic ones (Table 3, entries 1-4). Regarding the mechanism, the formation of a hydrogen bond between protic solvents $(\mathrm{B}-\mathrm{H})$ and the oxygen atom of the carbonyl groups of diketone compound increased the electrophilic character of carbonyl groups. Intramolecular nucleophilic attack at the carbon atom of carbonyl compound by the nitrogen atom of the amine group (via the intermediate I) was followed by intramolecular proton transfer in NP (see Scheme 3). Thus, the simultaneous activation of the carbonyl 
compound and protic solvents took place through the hydrogen bond formation with protic solvents. The time of the model reaction in $\mathrm{H}_{2} \mathrm{O}$ extended to a longer span than the other protic solvents, but their yields remained relatively unchanged because the reagents were not dissolved well in $\mathrm{H}_{2} \mathrm{O}$ (Table 3, entries 1 and 4) $[58,66,67]$. The best result was obtained from methanol, with the desired product 3a collected with the yield of $98 \%$ (Table 3, entry 3). This observation supported the involvement of hydrogen bond formation, where the solvation of the compounds increased with an increase in the polarity of the solvent. As the polarity of methanol was higher than ethanol, it acted as a better proton $\left(\mathrm{H}^{+}\right)$donor [68], being more effective in hydrogen bond formation with both solving reagent and activating carbonyl groups (intermediate I and II, shown in Scheme 3).

Table 3. Effect of various solvents on the synthesis of 3a by using NP as the catalyst.

\begin{tabular}{|c|c|c|c|}
\hline $1 \mathbf{a}$ & $\int_{O_{2 a}}^{P h}$ & $\frac{g)}{m L), r t}$ & 3a \\
\hline Entry & Solvent & Time (min) & Isolated Yield 3a (\%) \\
\hline 1 & $\mathrm{H}_{2} \mathrm{O}$ & 120 & 98 \\
\hline 2 & $\mathrm{EtOH}$ & 30 & 95 \\
\hline 3 & $\mathrm{MeOH}$ & 10 & 98 \\
\hline 4 & EtOH: $\mathrm{H}_{2} \mathrm{O}(1: 1)$ & 120 & 96 \\
\hline 5 & EtOAc & 120 & 70 \\
\hline 6 & $\mathrm{CH}_{3} \mathrm{CN}$ & 90 & 93 \\
\hline 7 & $\mathrm{Et}_{2} \mathrm{O}$ & 30 & 91 \\
\hline 8 & 1,4-dioxane & 20 & 93 \\
\hline 9 & DMSO & 30 & 91 \\
\hline
\end{tabular}

By varying the weight of NP (Table 4, entries 1-6), the model reaction progressed with a good yield of product $3 \mathrm{a}$ in the absence of a catalyst, so methanol could act as the co-catalyst (Table 4, entry 1 ). In terms of both reaction time and yield of product $3 a$, the best result was obtained by using $0.003 \mathrm{~g}$ of NP (Table 4, entry 4). The major constituent of NP is fluorapatite, so, experiments were carried out to verify the catalytic activity of fluorapatite. SFAP was prepared as explained in the experimental Section 3.2 [36] and used in the model reaction as the catalyst (Table 4 , entries 7 and 8). SFAP was not as effective as NP under the same reaction conditions, as it required a higher quantity of catalyst and a longer reaction time (Table 4, entries 7 and 8). From the XRD analysis (Figure 2), the comparable catalytic activity of NP and SFAP was independent of lattice parameters and the average crystallite size of NP. The higher catalytic activity of NP was originated from fluorapatite in addition to the low content of some phases, such as coesite, $\mathrm{SiO}_{2}[48]$ and hematite, $\mathrm{Fe}_{2} \mathrm{O}_{3}$ [69]. So, we performed the model reaction in the presence of the prepared $\mathrm{Fe}_{2} \mathrm{O}_{3}$ and $\mathrm{SiO}_{2}$ in order to examine their catalytic effects (Table 4, entries 9 and 10). The obtained results confirmed the fingerprint of $\mathrm{SiO}_{2}$ and $\mathrm{Fe}_{2} \mathrm{O}_{3}$ in the catalytic activity. It is likely that the moderate incorporation of $\mathrm{SiO}_{2}$ and $\mathrm{Fe}_{2} \mathrm{O}_{3}$ resulted in the higher catalytic activity of NP than SFAP [65] (Table 4, entry 10). The oxygen atoms of $\mathrm{CaO}$ and $\mathrm{P}_{2} \mathrm{O}_{5}$ (fluorapatite) [70], $\mathrm{SiO}_{2}$ [71] and $\mathrm{Fe}_{2} \mathrm{O}_{3}$ [60] in NP acted as the bases to attract the hydrogen of primary amine through hydrogen bonding [14]. In addition to these, the active Lewis acidic sites of $\mathrm{Fe}_{2} \mathrm{O}_{3}$ [72] would play a key role in increasing the electrophilic properties of carbonyl groups. 
Table 4. Effect of various amounts of catalyst on the synthesis of $\mathbf{3 a}$.

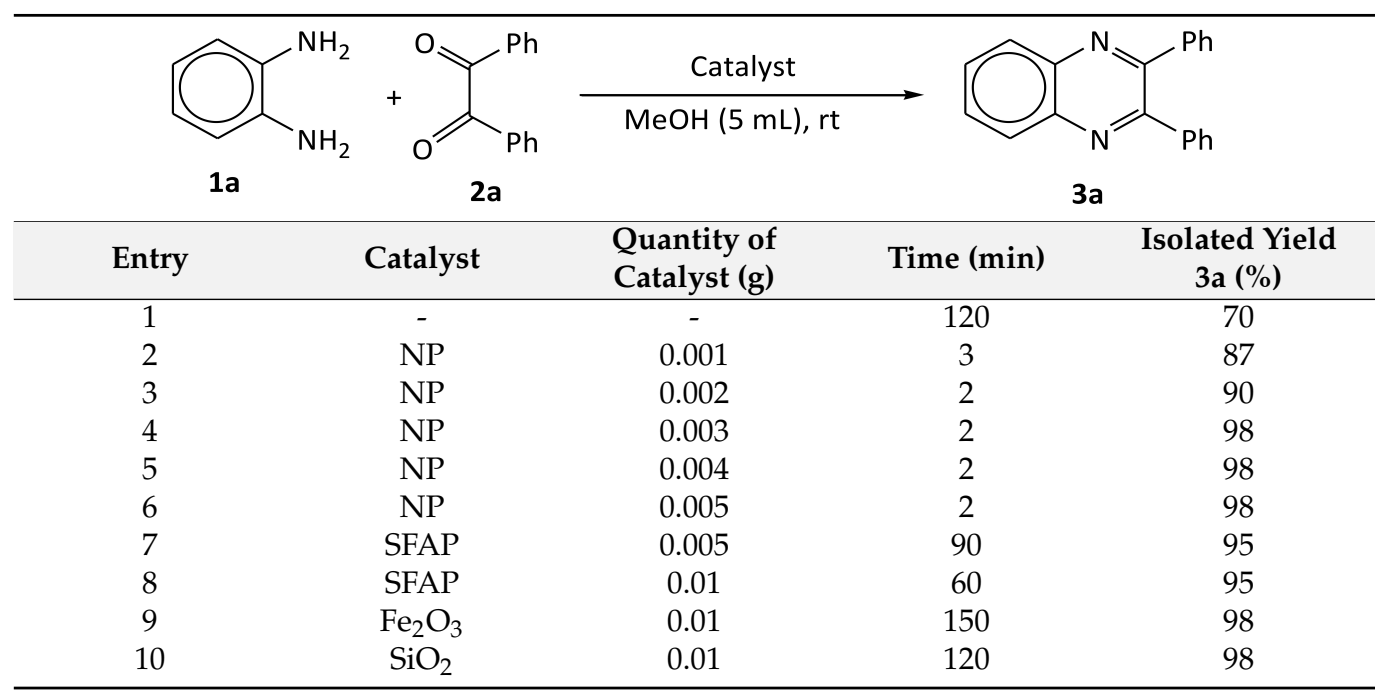

After the first cycle with a $98 \%$ yield of quinoxaline 3a, the catalyst was recovered by filtration, washing with acetone, drying and calcination at $900{ }^{\circ} \mathrm{C}$ in air for $30 \mathrm{~min}$. Then, the reusability of NP was studied by examining the model reaction under optimized conditions (Figure 8). The results show that the catalyst could be recycled for at least six runs without significant loss of catalytic activity; as shown in Table 2, this could be due to decreasing the surface area and pore volume of recycled NP, which may facilitate the strong adsorption of a small amount of either quinoxaline 3a or other unknown by-products. As mentioned earlier in Figure 7, decreasing the amount of Fe in the recycled NP could cause low yields of $\mathbf{3 a}$ at the longer reaction times, in which $\mathrm{Fe}^{3+}$ acted as Lewis acid and catalyzed the reaction.

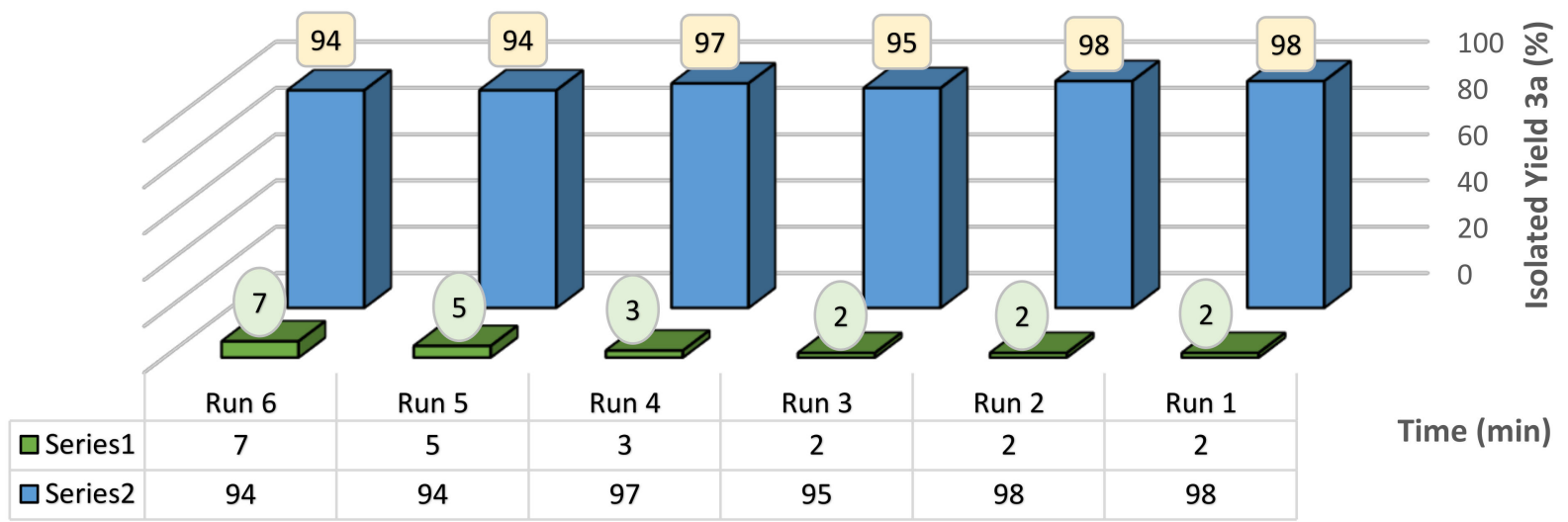

Figure 8. Recyclability of NP for the synthesis of quinoxaline 3a. Reaction conditions: with 1,2-Penylen-diamine (1 mmol), benzil $(1 \mathrm{mmol})$ and $\mathrm{NP}(0.003 \mathrm{~g})$ in $\mathrm{MeOH}(5 \mathrm{~mL})$ at room temperature.

To assess the generality and scope of the proposed method, the optimized reaction conditions were applied to various 1,2-diamines and 1,2-dicarbonyl compounds (Table 5). The reactions proceeded efficiently at room temperature. The corresponding quinoxalines were obtained with high to excellent yields at short reaction times without any side reactions. 
Table 5. Synthesis of quinoxalines 3 by using NP and SFAP as catalysts.

\begin{tabular}{|c|c|c|c|c|}
\hline \multirow{2}{*}{ Entry } & \multirow{2}{*}{ Diketone } & \multirow{2}{*}{ Product 3} & \multicolumn{2}{|c|}{ Time/Isolated Yield 3 (min/\%) } \\
\hline & & & NP & SFAP \\
\hline 1 & & & $2 / 98$ & $60 / 95$ \\
\hline 2 & & & $1 / 99$ & $60 / 97$ \\
\hline 3 & & & 2/99 & $55 / 95$ \\
\hline 4 & & & $1 / 99$ & $60 / 97$ \\
\hline 5 & & & $30 / 95$ & $90 / 92$ \\
\hline 6 & & & $40 / 96$ & $100 / 88$ \\
\hline 7 & & & $15 / 93$ & $70 / 90$ \\
\hline
\end{tabular}


Table 5. Cont.

\begin{tabular}{|c|c|c|c|c|}
\hline \multirow{2}{*}{ Entry } & \multirow{2}{*}{ Diketone } & \multirow{2}{*}{ Product 3} & \multicolumn{2}{|c|}{ Time/Isolated Yield 3 (min/\%) } \\
\hline & & & NP & SFAP \\
\hline 8 & & & $10 / 95$ & $70 / 92$ \\
\hline 9 & & & $12 / 97$ & $80 / 95$ \\
\hline 10 & & & $12 / 95$ & $70 / 88$ \\
\hline 11 & & & $10 / 97$ & $70 / 95$ \\
\hline 12 & & & $45 / 90$ & $120 / 87$ \\
\hline 13 & & & $10 / 93$ & $80 / 92$ \\
\hline 14 & & & $5 / 94$ & $70 / 91$ \\
\hline 15 & & & $20 / 96$ & $110 / 92$ \\
\hline & $\mathrm{O}$ & 30 & & \\
\hline
\end{tabular}


Table 5. Cont.

\begin{tabular}{llll}
\hline Entry & Diketone & \multicolumn{2}{c}{ Time/Isolated Yield 3 (min/\%) } \\
NP
\end{tabular}

Reaction condition: 1,2-diamine (1 mmol), 1,2-diketone (1 mmol), methanol $(5 \mathrm{~mL})$, NP $(0.003 \mathrm{~g})$ or SFAP $(0.01 \mathrm{~g})$ at room temperature.

Here, the activity and efficiency of catalysts for the synthesis of quinoxaline are compared with those previously reported (Table 6). Solid phase synthesis of quinoxaline using solid materials, such as K10 [73], alumina [74], silica [71] and graphite [75], needs longer reaction times or harsh reaction conditions (Table 6, entries 1-4). With a polymer as support, in addition to the multi-step preparation process (Table 6, entry 15), no data were found regarding the reusability of the catalyst (Table 6, entries 5-7). Other catalysts suffer from cost inefficiency and/or longer reaction times (Table 6, entry 8-13). $\mathrm{NH}_{4} \mathrm{Cl}$ results in high yield but it requires a larger quantity of catalyst for the reaction (Table 6, entry 14). Using MIL-101-Cr-NH-RSO 33 and nanostructured pyrophosphate $\mathrm{Na}_{2} \mathrm{PdP}_{2} \mathrm{O}_{7}$ suffers from its difficult, multi-step and costly routes as well as extra material preparation (Table 6, entries 15 and 16). NP is a low-cost, readily available and natural solid catalyst which can be stored at ambient temperature without losing its catalytic potential after recycling by simple filtration (Table 6, entry 17), while SFAP needs more reaction time and catalyst (Table 6, entry 18).

Table 6. Synthesis of quinoxaline using different catalysts.

\begin{tabular}{|c|c|c|c|c|}
\hline Entry & Catalyst & $\begin{array}{l}\text { Temperature/Solvent/Time } \\
\text { ( } \mathrm{C} /-/ \mathrm{min})\end{array}$ & Yield 3a (\%) & Reference \\
\hline 1 & Mont K-10 (10 mol \%) & $25 / \mathrm{H}_{2} \mathrm{O} / 150$ & 100 & [73] \\
\hline 2 & Alumin $^{\mathrm{a}}(0.2 \mathrm{~g})$ & $80 /$ Solvent-free/2 & 96 & [74] \\
\hline 3 & Silica gel $(1.0 \mathrm{~g})$ & Grind,100/Solvent-free/45 & 94 & [71] \\
\hline 4 & Graphite (2 mmol) & $\mathrm{rt} / \mathrm{EtOH} / 60$ & 92 & [75] \\
\hline 5 & $\mathrm{Zr}-\mathrm{CAP}-\mathrm{SGa}$ & $\mathrm{rt} / \mathrm{EtOH} / 90$ & 92 & [30] \\
\hline 6 & SBA-Pr-SO ${ }_{3} \mathrm{H}^{\mathrm{b}}(0.02 \mathrm{~g})$ & $\mathrm{rt} / \mathrm{CH}_{2} \mathrm{Cl}_{2} / 10$ & 95 & [76] \\
\hline 7 & PVPP.OTf $^{\mathrm{c}}(30 \mathrm{mg})$ & $\mathrm{rt} / \mathrm{H}_{2} \mathrm{O} / 60$ & 90 & [77] \\
\hline 8 & Nano $\mathrm{ZrO}_{2}(0.004 \mathrm{~g})$ & $60 / \mathrm{EtOH} / 2$ & 95 & [78] \\
\hline 9 & $\mathrm{MnFe}_{2} \mathrm{O}_{4} \mathrm{NP}^{\mathrm{d}}(10 \mathrm{~mol} \%)$ & $\mathrm{rt} / \mathrm{EtOH} / 150$ & 91 & [79] \\
\hline 10 & $\mathrm{Mn} / \mathrm{Al}_{2} \mathrm{O}_{3}$ & 50/EtOH:H2O/45 & 95 & [80] \\
\hline 11 & $\mathrm{SbCl}_{3} / \mathrm{SiO}_{2}(2.5 \mathrm{~mol} \%)$ & $\mathrm{rt} / \mathrm{MeOH} / 60$ & 98 & [81] \\
\hline 12 & $\mathrm{ZrCl}_{4}(5 \mathrm{~mol} \%)$ & $\mathrm{rt} / \mathrm{MeOH} / 240$ & 98 & [82] \\
\hline 13 & $\mathrm{SnCl}_{2} / \mathrm{SiO}_{2}(5 \mathrm{~mol} \%)$ & $\mathrm{rt} / \mathrm{MeOH} / 4$ & 100 & [83] \\
\hline 14 & $\mathrm{NH}_{4} \mathrm{Cl}(200 \mathrm{~mol} \%)$ & $\mathrm{rt} / \mathrm{MeOH} / 5$ & 100 & [84] \\
\hline 15 & MIL-101-Cr-NH-RSO ${ }_{3} \mathrm{H}^{\mathrm{e}}\left(3.9 \mathrm{~mol} \%-\mathrm{SO}_{3} \mathrm{H}\right)$ & $45 / \mathrm{MeOH} / 5$ & 91 & [28] \\
\hline 16 & Nanostructured pyrophosphate $\mathrm{Na}_{2} \mathrm{PdP}_{2} \mathrm{O}_{7}$ & $\mathrm{rt} / \mathrm{EtOH} / 30$ & 98 & [21] \\
\hline 17 & $\mathrm{NP}(0.003 \mathrm{~g})$ & $\mathrm{rt} / \mathrm{MeOH} / 2$ & 98 & This study \\
\hline 18 & SFAP $(0.01 \mathrm{~g})$ & $\mathrm{rt} / \mathrm{MeOH} / 60$ & 95 & This study \\
\hline
\end{tabular}

Reaction conditions: 1,2-Penylen-diamine $(1 \mathrm{mmol})$, benzil $(1 \mathrm{mmol})$ and catalyst. ${ }^{\mathrm{a}} \mathrm{Zr}(\mathrm{IV})$ modified on silica gel. ${ }^{\mathrm{b}}$ Sulfonic Acid Functionalized Nanoporous Silica (SBA-Pr- $\mathrm{SO}_{3} \mathrm{H}$ ). ${ }^{c}$ Polyvinylpolypyrrolidone supported triflic acid (PVPP.OTf). ${ }^{\mathrm{d}} \mathrm{MnFe}_{2} \mathrm{O}_{4}$ nanoparticles. e Alkyl sulfonate functionalized metal organic frameworks (MOFs).

After clarifying the role of NP, a mechanism is proposed in Scheme 3 for the facile formation of quinoxalines. The surface of NP presents multi-catalytic active sites (oxygen atoms of $\mathrm{P}_{2} \mathrm{O}_{5}$ or $\mathrm{PO}_{4}$ group and $\mathrm{CaO}$ ) [85-87] where the aminic hydrogen $(\mathrm{NH})$ of diamine (1) with the oxygens on the surface of NP and also protic solvent (B-H) can form doubly $\mathrm{H}$-bonded motifs with the oxygen atoms of carbonyl group of diketone (Intermediate I). 
Enhancing the nitrogen electrophilicity of the aminic group of 1,2-diamine followed by the nucleophilic attack of amine on the carbonyl carbon (Intermediate I) [75,88], along with the protonation and subsequent dehydration (Intermediate II), ended with the production of quinoxaline 3 and regenerating NP. Thus, NP accelerated the cyclocondensation process beside the HB-assisted activation [89].

\section{Materials and Methods}

All chemicals were purchased from Merck, Germany, and Sigma Aldrich, USA. The structural data of all synthesized products were compared with the authentic data from the literature. The chemical composition of NP was determined using a PANalytical XRF spectrometer Venus 200 (Malvern PANalytical Ltd, Malvern, UK). The surface imaging was obtained by using an SEM, EM-3200 (KYKY Technology Development Ltd. Zhongguancun, Beijing, China). XRD were performed at room temperature on a Philips 1710 diffractometric goniometer (Philips Technology Inc., Amsterdam, The Netherlands), mounted with a BraggBrentano configuration $(\theta, 2 \theta)$ and using Ni-filtered $C u-K_{\alpha}$ radiation $(\lambda=1.54 \AA)$ along with PANalytical XPert HighScore Plus software (Malvern PANalytical Ltd., Malvern, UK). Surface areas were determined at $77 \mathrm{~K}$ using a Coulter SA 31000 instrument with an automated gas volumetric method by employing nitrogen as the adsorbate through the BET and BJH methods (Beckman Coulter Inc., Brea, CA, USA). The EDX pattern was attained by using a stdLess Rontec analyzer (TScan company, Waltham, MA, USA). The pH measurements were performed using a microprocessor $\mathrm{pH}$ meter (Metrohm, $827 \mathrm{pH} \mathrm{Lab)}$ (Metrohm AG, Herisau, Switzerland). Melting points were recorded by utilizing a Buchi B540 melting point apparatus. Fourier-transform infrared (FT-IR) spectra were recorded on a Bruker Perkin-Elmer spectrometer with $\mathrm{KBr}$ pellets for solids (Bruker company, Billerica, MA, USA). The ${ }^{1} \mathrm{H}$ and ${ }^{13} \mathrm{C}$ NMR spectra were recorded on a $400 \mathrm{MHz}$ machine, Bruker Advance DRX spectrometer in $\mathrm{CDCl}_{3}$, using tetramethylsilane as an internal reference.

\subsection{Preparation of NP}

NP was collected from a known ore extract site, the Bafgh region, in Yazd province, Iran. This kind of NP is used by various local industries to prepare phosphate fertilizer and phosphoric acid [7]. The extracted NP was pre-treated by refluxing in water, calcinating at $900{ }^{\circ} \mathrm{C}$ in air for $2 \mathrm{~h}$, washing with water and finally re-calcinating at $900{ }^{\circ} \mathrm{C}$ in air for half an hour prior to usage as the catalyst [12].

\subsection{Synthesis of SFAP}

SFAP was prepared according to the method introduced by Sebti et al. [36]. A solution of di-ammonium hydrogen phosphate $\left(\left(\mathrm{NH}_{4}\right)_{2} \mathrm{HPO}_{4}, 7.92 \mathrm{~g}\right)$, ammonium fluoride $\left(\mathrm{NH}_{4} \mathrm{~F}\right.$, $1 \mathrm{~g})$, and double distilled water $(250 \mathrm{~mL})$ was prepared for further usage. The $\mathrm{pH}$ of the solution was adjusted to $\mathrm{pH}>12$ by using ammonium hydroxide $\left(\mathrm{NH}_{4} \mathrm{OH}\right)$; subsequently, calcium nitrate solution $\left(\mathrm{Ca}\left(\mathrm{NO}_{3}\right)_{2} \cdot 4 \mathrm{H}_{2} \mathrm{O}, 23.6 \mathrm{~g}\right)$ in double distilled water $(150 \mathrm{~mL})$ was slowly added to the mixture. The resultant suspension was refluxed for $4 \mathrm{~h}$. The reaction mixture was cooled down to room temperature, and the solid particles were collected, washed with water and dried overnight at $80^{\circ} \mathrm{C}$. Finally, the dried sample was calcined at $800{ }^{\circ} \mathrm{C}$ in air for $1 \mathrm{~h}$ to obtain SFAP.

\subsection{Measuring the Point of Zero Charge $\left(\mathrm{pH}_{p z c}\right)$}

To show the basicity of the surface of $\mathrm{NP}, \mathrm{pH}_{\mathrm{pzc}}$ was measured. $\mathrm{pHs}$ of a series of $50 \mathrm{~mL} 0.01 \mathrm{M} \mathrm{NaCl}$ solutions were adjusted to values between 2 and 12 by adding $\mathrm{HCl}$ $(0.1 \mathrm{M})$ or $\mathrm{NaOH}(0.1 \mathrm{M})$ solutions in a closed Erlenmeyer flask. The $\mathrm{pH}$ values of these solutions were recorded as initial $\mathrm{pH}\left(\mathrm{pH}_{\mathrm{I}}\right)$. Then, $0.2 \mathrm{~g}$ of NP was added to them to reach the final $\mathrm{pH}\left(\mathrm{pH}_{\mathrm{F}}\right)$ measured after $48 \mathrm{~h}$. The values of $\mathrm{pH}_{\mathrm{F}}$ vs. $\mathrm{pH}_{\mathrm{I}}$ and $\mathrm{pH} \mathrm{H}_{\mathrm{I}} \mathrm{vs}$. $\mathrm{pH}_{\mathrm{I}}$ were plotted to obtain $\mathrm{pH}_{\mathrm{pzc}}$ at their intersections [49]. 


\subsection{Synthesis of Quinoxalines}

In a typical reaction, a mixture of substituted cyclic 1,2-diamine $1(1 \mathrm{mmol})$ and diketone $2(1 \mathrm{mmol})$ was dissolved in methanol $(5 \mathrm{~mL})$. To this solution, NP $(0.003 \mathrm{~g})$ or SFAP $(0.01 \mathrm{~g})$ was added and stirred vigorously for 1-45 $\mathrm{min}$ for NP and 60-120 min for SFAP at room temperature. After completing the reaction, the mixture was filtered and washed with methanol $(5 \mathrm{~mL})$ in order to separate the catalyst. After the filtration, the methanolic filtrate was evaporated under vacuum to afford a crude product. Spectral data of obtained quinoxaline are presented in the Supplementary Information (SI).

\section{Conclusions}

The new use of natural phosphate was found as an efficient, inexpensive, recyclable and heterogeneous basic catalyst. This kind of NP could be stored at ambient temperature without majorly losing its catalytic potential after recycling by simple restoration filtering. NP catalyzed the condensation of 1,2-diamines with 1,2-diketones compounds in methanol at room temperature as an efficient way for the synthesis of quinoxaline derivatives with excellent yields in very short reaction time. The catalytic activity of the main component of natural phosphate was individually investigated. NP was characterized to be rich in fluorapatite as the major phase and minor phases of coesite $\left(\mathrm{SiO}_{2}\right)$ and hematite $\left(\mathrm{Fe}_{2} \mathrm{O}_{3}\right)$. So, the synthetic fluorapatite (SFAP), $\mathrm{SiO}_{2}$ and $\mathrm{Fe}_{2} \mathrm{O}_{3}$ were prepared, and their catalytic activities were compared with natural phosphate in the reaction. NP catalysed the quinoxaline reaction with the high yield and much shorter reaction time $(0.003 \mathrm{~g}, 98 \%$ yield in $2 \mathrm{~min}$ (for 3a product)) when compared to SFAP ( $0.01 \mathrm{~g}, 95 \%$ yield in $60 \mathrm{~min}), \mathrm{SiO}_{2}(0.01 \mathrm{~g}$, $98 \%$ yield in $120 \mathrm{~min}$ ) and $\mathrm{Fe}_{2} \mathrm{O}_{3}(0.01 \mathrm{~g}$, 98\% yield in $150 \mathrm{~min})$. NP had a low cost, a simple procedure, ready availability and good reusability for at least six runs without a major loss for the synthesis of quinoxalines at room temperature.

Supplementary Materials: The following are available online at https:/ / www.mdpi.com/article/ $10.3390 /$ ijms222413665/s1.

Author Contributions: A.A. Conceptualization, visualization, formal analysis, investigation, resources, supervision, project administration, funding acquisition, and writing—review; A.F., Conceptualization, visualization, formal analysis, investigation, validation, software, methodology, data curation, and writing; A.S., A.G., C.C., A.R.G., formal analysis, methodology, suggestions, resources, editing. All authors have read and agreed to the published version of the manuscript.

Funding: This research received no external funding.

Institutional Review Board Statement: No applicable.

Acknowledgments: The Australian College of ACK is highly acknowledged for the Research Grants No: IRC-2020/2021-SOE-ME-PR05 and PR06. Special thanks go to Mahmoud Tajbakhsh from the Department of Organic Chemistry, University of Mazandaran, Babolsar, Iran, for his valuable comments and humble support. We are grateful to Mazandaran University of Medical Sciences for providing laboratory facilities to carry out this research.

Conflicts of Interest: The authors declare no conflict of interest.

\section{References}

1. Fazeli-Attar, S.A.; Mirjalili, B.B.F. Synthesis of quinoxalines using Gum Arabic as a nontoxic metal-free biocatalyst at room temperature in aqueous media. Environ. Chem. Lett. 2018, 16, 671-676. [CrossRef]

2. Chassaing, S.; Beneteau, V.; Louis, B.; Pale, P. Zeolites as green catalysts for organic synthesis: The cases of H-, Cu-\& Sc-zeolites. Curr. Org. Chem. 2017, 21, 779-793.

3. Stokes, T.N.; Bromiley, G.D.; Potts, N.J.; Saunders, K.E.; Miles, A.J. The effect of melt composition and oxygen fugacity on manganese partitioning between apatite and silicate melt. Chem. Geol. 2019, 506, 162-174. [CrossRef]

4. Kruanak, K.; Jarusutthirak, C. Degradation of 2,4,6-trichlorophenol in synthetic wastewater by catalytic ozonation using alumina supported nickel oxides. J. Environ. Chem. Eng. 2019, 7, 102825. [CrossRef]

5. Wu, J.; Wang, B.; Blaney, L.; Peng, G.; Chen, P.; Cui, Y.; Deng, S.; Wang, Y.; Huang, J.; Yu, G. Degradation of sulfamethazine by persulfate activated with organo-montmorillonite supported nano-zero valent iron. Chem. Eng. J. 2019, 361, 99-108. [CrossRef] 
6. Tahir, R.; Banert, K.; Sebti, S. Natural and synthetic phosphates: New and clean heterogeneous catalysts for the synthesis of 5-arylhydantoins. Appl. Catal. A Gen. 2006, 298, 261-264. [CrossRef]

7. El Bamiki, R.; Raji, O.; Ouabid, M.; Elghali, A.; Khadiri Yazami, O.; Bodinier, J.-L. Phosphate Rocks: A Review of Sedimentary and Igneous Occurrences in Morocco. Minerals 2021, 11, 1137. [CrossRef]

8. Tan, Y. Process Simulation of the Influence of Phosphate Rock Impurities on the Production Index of Superphosphate. IOP Conf. Ser. Earth Environ. Sci. 2021, 772, 012047-101254. [CrossRef]

9. Glaser, B.; Lehr, V.-I. Biochar effects on phosphorus availability in agricultural soils: A meta-analysis. Sci. Rep. 2019, 9, 9338. [CrossRef]

10. Anawati, J.; Azimi, G. Recovery and separation of phosphorus as dicalcium phosphate dihydrate for fertilizer and livestock feed additive production from a low-grade phosphate ore. RSC Adv. 2020, 10, 38640-38653. [CrossRef]

11. Sebti, S.D.; Saber, A.; Rhihil, A.; Nazih, R.; Tahir, R. Claisen-Schmidt condensation catalysis by natural phosphate. Appl. Catal. A Gen. 2001, 206, 217-220. [CrossRef]

12. Bazi, F.; El Badaoui, H.; Tamani, S.; Sokori, S.; Solhy, A.; Macquarrie, D.; Sebti, S. A facile synthesis of amides by selective hydration of nitriles using modified natural phosphate and hydroxyapatite as new catalysts. Appl. Catal. A Gen. 2006, 301, 211-214. [CrossRef]

13. Dakkach, M.; Atlamsani, A.; Sebti, S. Natural phosphate as heterogeneous catalyst for oxidation of cyclic ketones to keto acids in environmentally friendly media. Mater. Environ. Sci. 2014, 5, 2122-2128.

14. Fallah, A.; Tajbakhsh, M.; Vahedi, H.; Bekhradnia, A. Natural phosphate as an efficient and green catalyst for synthesis of tetraketone and xanthene derivatives. Res. Chem. Intermed. 2017, 43, 29-43. [CrossRef]

15. Amini, A.; Fallah, A.; Cheng, C.; Tajbakhsh, M. Natural phosphate-supported Cu (II), an efficient and recyclable catalyst for the synthesis of xanthene and 1, 4-disubstituted-1, 2, 3-triazole derivatives. RSC Adv. 2018, 8, 41536-41547. [CrossRef]

16. Ji, H.-X.; Huang, Z.-S.; Wang, L.; Cao, D. Quinoxaline-based organic dyes for efficient dye-sensitized solar cells: Effect of different electron-withdrawing auxiliary acceptors on the solar cell performance. Dyes Pigm. 2018, 159, 8-17. [CrossRef]

17. Xing, Z.; Wu, W.; Miao, Y.; Tang, Y.; Zhou, Y.; Zheng, L.; Fu, Y.; Song, Z.; Peng, Y. Recent advances in quinazolinones as an emerging molecular platform for luminescent materials and bioimaging. Org. Chem. Front. 2021, 8, 1867-1889. [CrossRef]

18. Li, Y.; Wang, Z.; Zhang, C.; Gu, P.; Chen, W.; Li, H.; Lu, J.; Zhang, Q. Thiadizoloquinoxaline-Based N-Heteroacenes as Active Elements for High-Density Data-Storage Device. ACS Appl. Mater. Interfaces 2018, 10, 15971-15979. [CrossRef]

19. Ma, C.; Taghour, M.S.; Belal, A.; Mehany, A.B.; Mostafa, N.; Nabeeh, A.; Eissa, I.H.; Al-Karmalawy, A.A. Design and Synthesis of New Quinoxaline Derivatives as Potential Histone Deacetylase Inhibitors Targeting Hepatocellular Carcinoma: In Silico, In Vitro, and SAR Studies. Front. Chem. 2021, 9, 725135. [CrossRef]

20. Khatoon, H.; Abdulmalek, E. Novel Synthetic Routes to Prepare Biologically Active Quinoxalines and Their Derivatives: A Synthetic Review for the Last Two Decades. Molecules 2021, 26, 1055. [CrossRef]

21. Dânoun, K.; Essamlali, Y.; Amadine, O.; Mahi, H.; Zahouily, M. Eco-friendly approach to access of quinoxaline derivatives using nanostructured pyrophosphate Na 2 PdP 2 O 7 as a new, efficient and reusable heterogeneous catalyst. BMC Chem. 2020, 14, 6. [CrossRef]

22. Rong, F.; Chow, S.; Yan, S.; Larson, G.; Hong, Z.; Wu, J. Structure-activity relationship (SAR) studies of quinoxalines as novel HCV NS5B RNA-dependent RNA polymerase inhibitors. Bioorg. Med. Chem. Lett. 2007, 17, 1663-1666. [CrossRef]

23. Smits, R.A.; Lim, H.D.; Hanzer, A.; Zuiderveld, O.P.; Guaita, E.; Adami, M.; Coruzzi, G.; Leurs, R.; de Esch, I.J. Fragment Based Design of New H4 Receptor- Ligands with Anti-inflammatory Properties in Vivo. J. Med. Chem. 2008, 51, 2457-2467. [CrossRef]

24. Hui, X.; Desrivot, J.; Bories, C.; Loiseau, P.M.; Franck, X.; Hocquemiller, R.; Figadère, B. Synthesis and antiprotozoal activity of some new synthetic substituted quinoxalines. Bioorg. Med. Chem. Lett. 2006, 16, 815-820. [CrossRef]

25. Irfan, A.; Ahmad, S.; Hussain, S.; Batool, F.; Riaz, H.; Zafar, R.; Kotwica-Mojzych, K.; Mojzych, M. Recent Updates on the Synthesis of Bioactive Quinoxaline-Containing Sulfonamides. Appl. Sci. 2021, 11, 5702. [CrossRef]

26. Maikhuri, V.K.; Prasad, A.K.; Jha, A.; Srivastava, S. Recent advances in the transition metal catalyzed synthesis of quinoxalines: A review. New J. Chem. 2021, 45, 13214-13246. [CrossRef]

27. Dhakshinamoorthy, A.; Kanagaraj, K.; Pitchumani, K. Zn ${ }^{2+}-\mathrm{K} 10$-clay (clayzic) as an efficient water-tolerant, solid acid catalyst for the synthesis of benzimidazoles and quinoxalines at room temperature. Tetrahedron Lett. 2011, 52, 69-73. [CrossRef]

28. Andriamitantsoa, R.S.; Wang, J.; Dong, W.; Gao, H.; Wang, G. $\mathrm{SO}_{3} \mathrm{H}$-functionalized metal organic frameworks: An efficient heterogeneous catalyst for the synthesis of quinoxaline and derivatives. RSC Adv. 2016, 6, 35135-35143. [CrossRef]

29. Pawar, O.B.; Chavan, F.R.; Suryawanshi, V.S.; Shinde, V.S.; Shinde, N.D. Thiamine hydrochloride: An efficient catalyst for one-pot synthesis of quinoxaline derivatives at ambient temperature. J. Chem. Sci. 2013, 125, 159-163. [CrossRef]

30. Sharma, R.; Sharma, C. Zirconium (IV)-modified silica gel: Preparation, characterization and catalytic activity in the synthesis of some biologically important molecules. Catal. Commun. 2011, 12, 327-331. [CrossRef]

31. Dang, G.H.; Vu, Y.T.H.; Dong, Q.A.; Le, D.T.; Truong, T.; Phan, N.T.S. Quinoxaline synthesis via oxidative cyclization reaction using metal-organic framework $\mathrm{Cu}(\mathrm{BDC})$ as an efficient heterogeneous catalyst. Appl. Catal. A Gen. 2015, 491, 189-195. [CrossRef]

32. Tajbakhsh, M.; Bazzar, M.; Ramzanian, S.F.; Tajbakhsh, M. Sulfonated nanoClay minerals as a recyclable eco-friendly catalyst for the synthesis of quinoxaline derivatives in green media. Appl. Clay Sci. 2014, 88, 178-185. [CrossRef] 
33. Indalkar, K.S.; Khatri, C.K.; Chaturbhuj, G.U. Rapid, efficient and eco-friendly procedure for the synthesis of quinoxalines under solvent-free conditions using sulfated polyborate as a recyclable catalyst. J. Chem. Sci. 2017, 129, 141-148. [CrossRef]

34. Jafarpour, M.; Rezapour, E.; Ghahramaninezhad, M.; Rezaeifard, A. A novel protocol for selective synthesis of monoclinic zirconia nanoparticles as a heterogeneous catalyst for condensation of 1,2-diamines with 1,2-dicarbonyl compounds. New J. Chem. 2014, 38, 676-682. [CrossRef]

35. Aashish, O.; Mahadeo, A.; Machhindra, K.; Balasaheb, R. Synthesis of Quinoxaline Derivatives at Room Temperature Using Magnetic Material Separated from Coal Fly Ash. J. Korean Chem. Soc. 2013, 57, 73-80.

36. Sebti, S.; Nazih, R.; Tahir, R.; Saber, A. Fluorapatite/sodium nitrate as a solid support for the Knoenenagel reaction. Synth. Commun. 2001, 31, 993-999. [CrossRef]

37. Hassine, A.; Sebti, S.; Solhy, A.; Zahouily, M.; Len, C.; Hedhili, M.N.; Fihri, A. Palladium supported on natural phosphate: Catalyst for Suzuki coupling reactions in water. Appl. Catal. A Gen. 2013, 450, 13-18. [CrossRef]

38. Bazi, F.; El Badaoui, H.; Tamani, S.; Sokori, S.; Oubella, L.; Hamza, M.; Boulaajaj, S.; Sebti, S. Catalysis by phosphates: A simple and efficient procedure for transesterification reaction. J. Mol. Catal. A Chem. 2006, 256, 43-47. [CrossRef]

39. Moshaverinia, A.; Ansari, S.; Movasaghi, Z.; Billington, R.W.; Darr, J.A.; Rehman, I.U. Modification of conventional glass-ionomer cements with $\mathrm{N}$-vinylpyrrolidone containing polyacids, nano-hydroxy and fluoroapatite to improve mechanical properties. Dent. Mater. 2008, 24, 1381-1390. [CrossRef]

40. Elliott, J.C. Structure and Chemistry of the Apatites and Other Calcium Orthophosphates; Elsevier: Amsterdam, The Netherlands, 2013.

41. Othmani, M.; Aissa, A.; Bac, C.G.; Rachdi, F.; Debbabi, M. Surface modification of calcium hydroxyapatite by grafting of etidronic acid. Appl. Surf. Sci. 2013, 274, 151-157. [CrossRef]

42. Wang, H.; Sun, K.; Li, A.; Wang, W.; Chui, P. Size-controlled synthesis and characterization of fluorapatite nanocrystals in the presence of gelatin. Powder Technol. 2011, 209, 9-14. [CrossRef]

43. Sebti, S.D.; Solhy, A.; Tahir, R.; Abdelatif, S.; Boulaajaj, S.D.; Mayoral, J.A.; Garcia, J.I.; Fraile, J.M.; Kossir, A.; Oumimoun, H. Application of natural phosphate modified with sodium nitrate in the synthesis of chalcones: A soft and clean method. J. Catal. 2003, 213, 1-6. [CrossRef]

44. Dorozhkin, S.V.; Epple, M. Biological and medical significance of calcium phosphates. Angew. Chem. Int. Ed. 2002, 41, 3130-3146. [CrossRef]

45. Saoiabi, S.; Laghzizil, A.; Lahlil, K.; Zrineh, A. Interaction of metal (II)-tetra (4-sulfonatophenyl) porphyrins with porous hydroxyapatite surfaces. J. Taiwan Inst. Chem. Eng. 2012, 43, 996-1001. [CrossRef]

46. Ramananarivo, H.R.; Solhy, A.; Sebti, J.; Smahi, A.; Zahouily, M.; Clark, J.; Sebti, S. An Eco-Friendly Paradigm for the Synthesis of $\alpha$-Hydroxyphosphonates Using Sodium-Modified Fluorapatite under Solventless Conditions. ACS Sustain. Chem. Eng. 2013, 1, 403-409. [CrossRef]

47. Bachouâ, H.; Othmani, M.; Coppel, Y.; Fatteh, N.; Debbabi, M.; Badraoui, B. Structural and thermal investigations of a Tunisian natural phosphate rock. J. Mater. Environ. Sci. 2014, 5, 1152-1159.

48. Musić, S.; Filipović-Vinceković, N.; Sekovanić, L. Precipitation of amorphous $\mathrm{SiO}_{2}$ particles and their properties. Braz. J. Chem. Eng. 2011, 28, 89-94. [CrossRef]

49. Nezamzadeh-Ejhieh, A.; Zabihi-Mobarakeh, H. Heterogeneous photodecolorization of mixture of methylene blue and bromophenol blue using CuO-nano-clinoptilolite. J. Ind. Eng. Chem. 2014, 20, 1421-1431. [CrossRef]

50. Chaïrat, C.; Oelkers, E.H.; Schott, J.; Lartigue, J.-E. Fluorapatite surface composition in aqueous solution deduced from potentiometric, electrokinetic, and solubility measurements, and spectroscopic observations. Geochim. Cosmochim. Acta 2007, 71, 5888-5900. [CrossRef]

51. Chaïrat, C.; Schott, J.; Oelkers, E.H.; Lartigue, J.-E.; Harouiya, N. Kinetics and mechanism of natural fluorapatite dissolution at 25 $\mathrm{C}$ and $\mathrm{pH}$ from 3 to 12. Geochim. Cosmochim. Acta 2007, 71, 5901-5912. [CrossRef]

52. Brunauer, S.; Deming, L.S.; Deming, W.E.; Teller, E. On a Theory of the van der Waals Adsorption of Gases. J. Am. Chem. Soc. 1940, 62, 1723-1732. [CrossRef]

53. Nathanael, A.J.; Mangalaraj, D.; Hong, S.; Masuda, Y.; Rhee, Y.; Kim, H. Influence of fluorine substitution on the morphology and structure of hydroxyapatite nanocrystals prepared by hydrothermal method. Mater. Chem. Phys. 2013, 137, 967-976. [CrossRef]

54. Smahi, A.; Solhy, A.; Tahir, R.; Sebti, S.; Mayoral, J.A.; García, J.I.; Fraile, J.M.; Zahouily, M. Preparation of $\alpha$-hydroxyphosphonates over phosphate catalysts. Catal. Commun. 2008, 9, 2503-2508. [CrossRef]

55. Ait Hmeid, H.; Akodad, M.; Baghour, M.; Moumen, A.; Skalli, A.; Azizi, G.; Gueddari, H.; Maach, M.; Aalaoul, M.; Anjjar, A.; et al. Valorization of Moroccan Bentonite Deposits: "Purification and Treatment of Margin by the Adsorption Process". Molecules 2021, 26, 5528. [CrossRef]

56. Elaheh Mosaddegh, A.H. Application and characterization of eggshell as a new biodegradable and heterogeneous catalyst in green synthesis of 7,8-dihydro-4H-chromen-5(6H)-ones. Catal. Commun. 2013, 33, 70-75. [CrossRef]

57. Senamaud, N.; Bernache-Assollant, D.; Champion, E.; Heughebaert, M.; Rey, C. Calcination and sintering of hydroxyfluorapatite powders. Solid State Ion. 1997, 101, 1357-1362. [CrossRef]

58. Huang, J.; Jiao, L.; Yang, Y.; Dong, Y.; Zhang, Y.; Chang, L.; Gong, M.; Li, J.; He, A.; Wang, X. Fe-6.5 wt\% Si Powder Cores with Low Core Loss by Optimizing Particle Size Distribution. Metals 2020, 10, 1699. [CrossRef]

59. Kale, S.R.; Kahandal, S.S.; Gawande, M.B.; Jayaram, R.V. Magnetically recyclable $\gamma-\mathrm{Fe}_{2} \mathrm{O}_{3}-\mathrm{HAP}$ nanoparticles for the cycloaddition reaction of alkynes, halides and azides in aqueous media. RSC Adv. 2013, 3, 8184-8192. [CrossRef] 
60. Parfitt, R.L.; Atkinson, R.J.; Smart, R.S.C. The Mechanism of Phosphate Fixation by Iron Oxides. Soil Sci. Am. J. 1975, 39, 837-841. [CrossRef]

61. Ouda, K.; Danninger, H.; Gierl-Mayer, C.; Hellein, R.; Müller, A. Ferrothermal reduction of iron (III) phosphate insulating layers in soft magnetic composites. Powder Metall. 2021, 64, 351-359. [CrossRef]

62. Siwek, H.; Bartkowiak, A.; Włodarczyk, M.; Sobecka, K. Removal of phosphate from aqueous solution using alginate/iron (III) chloride capsules: A laboratory study. Water Air Soil Pollut. 2016, 227, 427. [CrossRef]

63. Gypser, S. Identification of Phosphate Adsorption Mechanisms on Fe-and Al-Hydroxides and the Influence of Inorganic and Organic Compounds to Reduce Long-Term Phosphorus Fixation on Mineral Surfaces; BTU Cottbus-Senftenberg: Cottbus, Germany, 2019.

64. Kraushofer, F.; Jakub, Z.; Bichler, M.; Hulva, J.; Drmota, P.; Weinold, M.; Schmid, M.; Setvin, M.; Diebold, U.; Blaha, P.; et al. Atomic-Scale Structure of the Hematite $\alpha-\mathrm{Fe}_{2} \mathrm{O}_{3}(1102)$ "R-Cut" Surface. J. Phys. Chem. C 2018, 122, 1657-1669. [CrossRef]

65. Borhade, A.V.; Tope, D.R.; Patil, D.R. Nanocrystalline 5\% Fe/ZnO as an efficient catalyst for quinoxaline synthesis. Res. Chem. Intermed. 2013, 39, 1373-1383. [CrossRef]

66. Elumalai, V.; Hansen, J.H. A Green, Scalable, and Catalyst-Free One-Minute Synthesis of Quinoxalines. SynOpen 2021, 5, 43-48.

67. Robertson, R.; Heppolette, R.; Scott, J. A survey of thermodynamic parameters for solvolysis in water. Can. J. Chem. 1959, 37, 803-824. [CrossRef]

68. Pysanenko, A.; Gámez, F.; Fárníková, K.; Pluhařová, E.; Fárník, M. Proton Transfer Reactions between Methanol and Formic Acid Deposited on Free Ar N Nanoparticles. J. Phys. Chem. A 2019, 123, 7201-7209. [CrossRef]

69. Karasyova, O.N.; Ivanova, L.I.; Lakshtanov, L.Z.; Lövgren, L.; Sjöberg, S. Complexation of gold (III)-chloride at the surface of hematite. Aquat. Geochem. 1998, 4, 215-231. [CrossRef]

70. Wu, Y.-J.; Tsai, T.W.; Huang, S.-J.; Mou, Y.; Lin, C.-J.; Chan, J.C. Hydrogen bond formation between citrate and phosphate ions in spherulites of fluorapatite. Langmuir 2013, 29, 11681-11686. [CrossRef]

71. Nandi, G.C.; Samai, S.; Kumar, R.; Singh, M. Silica-Gel-Catalyzed Efficient Synthesis of Quinoxaline Derivatives Under SolventFree Conditions. Synth. Commun. 2011, 41, 417-425. [CrossRef]

72. Kataria, M.; Pramanik, S.; Kaur, N.; Kumar, M.; Bhalla, V. Ferromagnetic $\alpha-\mathrm{Fe}_{2} \mathrm{O}_{3}$ NPs: A potential catalyst in SonogashiraHagihara cross coupling and hetero-Diels-Alder reactions. Green Chem. 2016, 18, 1495-1505. [CrossRef]

73. Huang, T.-k.; Wang, R.; Shi, L.; Lu, X.-x. Montmorillonite K-10: An efficient and reusable catalyst for the synthesis of quinoxaline derivatives in water. Catal. Commun. 2008, 9, 1143-1147. [CrossRef]

74. Jafarpour, M.; Rezaeifard, A.; Danehchin, M. Easy access to quinoxaline derivatives using alumina as an effective and reusable catalyst under solvent-free conditions. Appl. Catal. A Gen. 2011, 394, 48-51. [CrossRef]

75. Kadam, H.K.; Khan, S.; Kunkalkar, R.A.; Tilve, S.G. Graphite catalyzed green synthesis of quinoxalines. Tetrahedron Lett. 2013, 54, 1003-1007. [CrossRef]

76. Ziarani, G.M.; Badiei, A.; Haddadpour, M. Application of sulfonic acid functionalized nanoporous silica $\left(\mathrm{SBA}^{-\mathrm{Pr}-\mathrm{SO}} \mathrm{H}_{3}\right)$ for one-pot synthesis of quinoxaline derivatives. Int. J. Chem. 2011, 3, 87-94.

77. Khaksar, S.; Tajbakhsh, M.; Gholami, M.; Rostamnezhad, F. A highly efficient procedure for the synthesis of quinoxaline derivatives using polyvinylpolypyrrolidone supported triflic acid catalyst (PVPP. OTf). Chin. Chem. Lett. 2014, 25, 1287-1290. [CrossRef]

78. Kolvari, E.; Zolfigol, M.A.; Koukabi, N.; Gilandust, M.; Kordi, A.-V. Zirconium triflate: An efficient catalyst for the synthesis of quinolines and quinoxalines. J. Iran. Chem. Soc. 2013, 10, 1183-1191. [CrossRef]

79. Brahmachari, G.; Laskar, S.; Barik, P. Magnetically separable $\mathrm{MnFe}_{2} \mathrm{O}_{4}$ nano-material: An efficient and reusable heterogeneous catalyst for the synthesis of 2-substituted benzimidazoles and the extended synthesis of quinoxalines at room temperature under aerobic conditions. RSC Adv. 2013, 3, 14245-14253. [CrossRef]

80. Rekha, M.; Kathyayini, H.; Nagaraju, N. Catalytic activity of manganese oxide supported on alumina in the synthesis of quinoxalines. Front. Chem. Sci. Eng. 2013, 7, 415-421. [CrossRef]

81. Darabi, H.R.; Aghapoor, K.; Mohsenzadeh, F.; Taala, F.; Asadollahnejad, N.; Badiei, A. Silica-supported antimony (III) chloride as highly effective and reusable heterogeneous catalyst for the synthesis of quinoxalines. Catal. Lett. 2009, 133, 84-89. [CrossRef]

82. Aghapoor, K.; Darabi, H.R.; Mohsenzadeh, F.; Balavar, Y.; Daneshyar, H. Zirconium (IV) chloride as versatile catalyst for the expeditious synthesis of quinoxalines and pyrido [2, 3-b] pyrazines under ambient conditions. Transit. Met. Chem. 2010, 35, 49-53. [CrossRef]

83. Darabi, H.R.; Aghapoor, K.; Mohsenzadeh, F.; Jalali, M.R.; Talebian, S.; Ebadi-Nia, L.; Khatamifar, E.; Aghaee, A. Heterogeneous $\mathrm{SnCl}_{2} / \mathrm{SiO}_{2}$ versus homogeneous $\mathrm{SnCl}_{2}$ acid catalysis in the benzo [N, N]-heterocyclic condensation. Bull. Korean Chem. Soc. 2011, 32, 213-218. [CrossRef]

84. Darabi, H.R.; Tahoori, F.; Aghapoor, K.; Taala, F.; Mohsenzadeh, F. $\mathrm{NH}_{4} \mathrm{Cl}_{-} \mathrm{CH}_{3} \mathrm{OH}$ : An efficient, acid-and metal-free catalyst system for the synthesis of quinoxalines. J. Braz. Chem. Soc. 2008, 19, 1646-1652. [CrossRef]

85. Bennazha, J.; Zahouilly, M.; Boukhari, A.; Holt, E.M. Investigation of the basis of catalytic activity of solid state phosphate complexes in the Knoevenagel condensation. J. Mol. Catal. A Chem. 2003, 202, 247-252. [CrossRef]

86. Bennazha, J.; Zahouily, M.; Sebti, S.; Boukhari, A.; Holt, E. $\mathrm{Na}_{2} \mathrm{CaP}_{2} \mathrm{O}_{7}$, a new catalyst for Knoevenagel reaction. Catal. Commun. 2001, 2, 101-104. [CrossRef]

87. Wu, L.; Forsling, W.; Schindler, P.W. Surface complexation of calcium minerals in aqueous solution: 1 . Surface protonation at fluorapatite-water interfaces. J. Colloid Interface Sci. 1991, 147, 178-185. [CrossRef] 
88. Baghbanian, S.M.; Farhang, M. Protic [TBD][TFA] ionic liquid as a reusable and highly efficient catalyst for N-formylation of amines using formic acid under solvent-free condition. J. Mol. Liq. 2013, 183, 45-49. [CrossRef]

89. Manna, C.; Samanta, S.K.; Ghosh, S.K.; Pathak, T. Synthesis of 1, 8-dioxo-octahydroxanthene C-nucleosides. Tetrahedron Lett. 2013, 54, 3971-3973. [CrossRef] 